\title{
Sticking to the Facts: Official and Unofficial Stories about Poverty and Unemployment in South Africa
}

\author{
Charles Meth \\ School of Development Studies \\ University of KwaZulu-Natal \\ \& \\ Southern African Labour and Development Research Unit \\ University of Cape Town \\ chasmeth@telkomsa.net
}

Development Policy Research Unit

DPRU Working Paper 07/123

ISBN Number: 978-1-920055-46-2

June 2007 


\section{Abstract}

Poverty's major cause is unemployment. In the unlikely event that unemployment is halved by 2014 , there will still be millions of people in South Africa in workerless households. The only way to address this is to develop a truly comprehensive social protection system. This paper looks at aspects of the way government responds to claims that are made, chiefly by academics, about poverty and unemployment. Bearers of good tidings are effusively welcomed while critics are dismissed with a hail of numbers about the achievements, actual or projected, of the democratic government.

Official statistics on poverty and unemployment enjoy little favour among senior politicians and civil servants. 'Unofficial' poverty and unemployment statistics, by contrast, are seized upon with enthusiasm if they contradict the gloomy picture created by numbers that suggest (with monotonous regularity) that improvements in the lives of the poor are not happening fast enough. The first part of the paper explores possible explanations of government's extreme sensitivity to criticism.

The second part of the paper looks at an old chestnut, the repeated claim by government that the severity of the unemployment problem has (in part?) to do with the 'fact' that the number of economically active people has grown faster than the number of working age people. The claim is false, and may readily be seen to be so. It sits awkwardly with the equally frequently repeated claim that 'we are on target to halve unemployment'. The usefulness of the (false) claim is presumably the sympathy and understanding it evokes for the plight of a government faced, in its attempts to solve an immensely difficult problem, by continually moving goalposts.

The third part of the paper looks briefly at the van der Berg et al (2005) poverty reduction estimates for the period 2000-2004 (they have the headcount falling from 18.5 to 15.4 million), before reproducing my estimates for the period 2001-2004 (the headcount falls from about 19.5 to somewhere in the region of 18 million). Extracted from two recent papers (Meth 2006a and 2006b), a brief description of the way these figures have been constructed, including a discussion of the many data difficulties faced in doing so, is offered. The van der Berg et al finding of a headcount fall of three million, said largely to be the result of massive expansion of the social grant system (and possible improved job creation) is argued to be dubious. My results suggest that the grants lifted an additional 1.2-1.5 million people over the poverty line. They also suggest that job creation benefited 
the well-off rather than the poor. Figures from a paper by Burger and Yu (2006), two of van der Berg's co-authors, suggest that earnings growth, the only other possible source of income for raising the poor out of poverty, cannot account for more than a trivial proportion of such movement out of poverty as did occur during the period.

Suggestions are offered for the proper academic conduct upon releasing contentious results into a highly-charged political debate.

\section{Acknowledgement}

This is a revised version of a paper that was presented at the DPRU/TIPS annual conference, Johannesburg, 18-20th October 2006. I am grateful to Debbie Budlender, who read and commented critically on the conference paper (as she has on so many of the things I have written). Anna McCord was subjected to several rehearsals of my struggle to develop an understanding of why politicians are so addicted to good news. For the rest, unnecessary though it should be to announce it, all errors and omissions in the paper are my very own.

Development Policy Research Unit Tel: +27 216505705

Fax: +27 216505711
Information about our Working Papers and other published titles are available on our website at: http://www.commerce.uct.ac.za/dprul 


\section{Table of Contents}

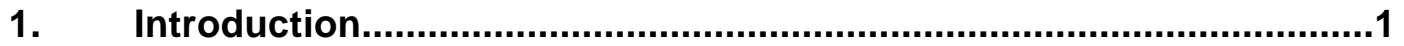

2. 'Facts', Artefacts and Anti-Poverty Policy.........................................

3. Misunderstanding Unemployment...............................................22

4. Progress in the Struggle Against Poverty? ...................................34

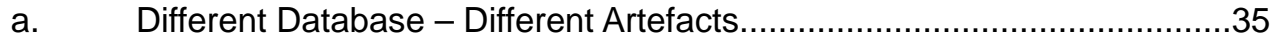

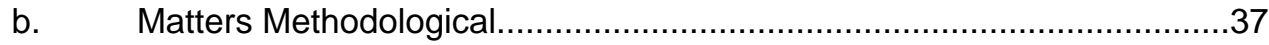

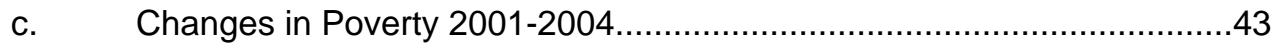

d. A Three-Million Headcount Fall, 2000-2004?..................................48

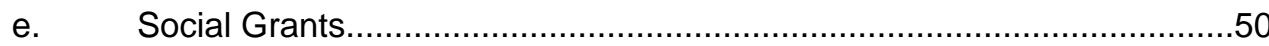

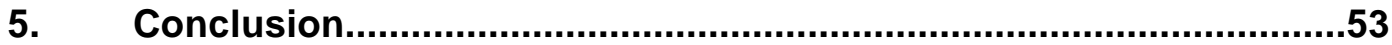

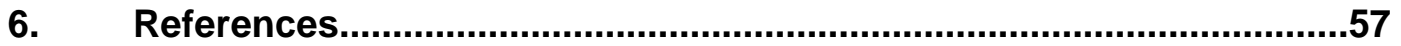

\section{Index of Tables}

Table 1: Numbers of Scholars Reporting Problems of Various Sorts at School - July 2005. .19

Table 2: Numbers of People Reporting Problems at Clinics during June 2005. .20

Table 3: Economic Activity, 1996-1999. .24

Table 4: Economic Activity, 2000-2005. .25

Table 5: The Break in the Series between 1999 and 2000. .26

Table 6: Poverty Estimates, 2004 - Income from all Sources. .42

Table 7: Poverty in South Africa, 2001-2004. .45 


\section{Introduction}

It can come as no surprise to anyone to hear that politicians and government officials are addicted to 'good news' about the efficacy of the policies they devise and attempt to implement; to expect otherwise, would be naïve in the extreme. On the face of it, therefore, a paper devoted to the examination of such an addiction, would seem to hold out little promise of revealing anything new. Since, however, the reasons why good news is craved can vary from the despicable (attempts to justify bad policies pursued by unpopular governments) to the sad (good policies introduced by a sympathetic government succeeding but not receiving the recognition that is their due), there are more than ample grounds for delving into the stories behind particular cravings for good news. Accordingly, this paper attempts to understand the particular reasons for the South African government's addiction to good news about its anti-poverty policies, and its policies to address unemployment. It does so by looking at the way that government communications experts impart a 'spin' to stories when the news they contain is not good enough.

Structural mass poverty has been the lot of most South Africans for a very long time; structural mass unemployment, ${ }^{1}$ its somewhat younger cousin, has had the country in its grip for almost three decades. ${ }^{2}$ Poverty among the majority of people in the country has been obvious for so long that even if the phenomenon did not attract the concentrated academic attention it deserved until the early 1980s (the Second Carnegie Conference in 1984 marks a turning point at which the trickle of research endeavours in the field, turns into a flood), few would have thought it appropriate to deny poverty's widespread existence. The history of the debate about unemployment is different. There was a time (in the late 1970s and early 1980s) when economists of a conservative (neo-classical) stripe denied the existence of 'involuntary' unemployment in South Africa, claiming that even if the 'going wage' was deplorably low, there was work for all who were prepared to accept

1 Discussing conditions in the world more generally, Lal and Myint (1996, pp.34-35) observe that structural mass poverty, "for most of our history, has been the natural state of humanity." Eradicated in the advanced capitalist (and for a while, in the advanced former socialist) countries by the two forces underpinning the capitalist 'industrial' revolution, the institutional changes noted by Adam Smith, and the unleashing of the immense power of mineral raw materials, first recognised by Marx, the problem of structural mass poverty gave way, under certain adverse conditions, to mass structural unemployment. The devastating unemployment of the Great Depression that followed the crash of 1929 was 'cured' in many countries only by full employment associated with World War II. The stability and near-full employment of the post-war period, which encouraged the conceit that the business cycle had finally been vanquished, was shattered by the crisis of the late 70s and early 80s, which saw the reemergence of sustained high rates of unemployment in many advanced capitalist countries. For evidence of the unemployment crisis in the OECD countries, see Scharpf and Schmidt (2000), Vol. 1, Table A.4, p.341. 'independent' Bantustans. The unemployment rate for Africans in what was quaintly described as the 'White areas' of South Africa was 13 per cent, while in the 'non-independent' Bantustans, it had reportedly reached 28 per cent. Meth (1988, p.173) 
that wage. It may well have been the case that the reservation wage of some of the unemployed exceeded the going rate for some of the less pleasant jobs in the economy. That is unlikely to be the case now. If the Labour Force Surveys (LFS) are to be believed such folk constitute a tiny minority of the unemployed, the bulk of whom report, when asked why they did not work in the previous week reply that they cannot find any work. ${ }^{3}$ Nowadays, it would be difficult to find serious support for the view that unemployment is 'voluntary'. Even though it is now widely accepted that South Africa's unemployment and poverty problems are serious, there are still major disagreements about the extent of each. There are disagreements as well, about the causes of each, and the effects, positive or negative, of government policy on both poverty and unemployment.

Since much of the disagreement about the unemployment and poverty problems, stems either from government's rejection of official statistics (unemployment) or its over-hasty endorsement of reports of reductions in the poverty headcount, a way of starting to think systematically about government's addiction to good news about its policies needs to be found. The approach adopted in this paper makes use of two aphorisms: one is Marx's claim that: 'If the essence and appearance of things directly coincided, all science would become superfluous'. The other is that: 'Justice must not only be done, it must also be seen to be done'. ${ }^{4}$

The essence of poverty, of course, is the lived experience of the poor. Appearance that obscures the nature of that essence, or that reflects only a fraction of the essence, is probably what the casual onlooker sees. ${ }^{5}$ Social science may be thought of as the attempt to reduce the distorting and refracting effects of the medium that separates essence and appearance. Scientific analysis can never recreate essence - the

3 In September 2004, the LFS found 722000 people who said that they lacked the skills or qualifications required for the available jobs, 231000 who said that they had recently been retrenched, and 6.75 million people who reported that they could not find any work. Almost 44 per cent of these people were below the poverty line of R250 per capita in 2000 prices (R309 per person in 2004 prices), while almost half of them were below a line of R400 per month (in 2004) prices. These poor people are unlikely to be choosey about jobs - only 294000 people reported not being able to find 'suitable work', where suitable is defined in terms of wage/salary, location or working conditions. Before September 2002, conservatives used to be able to argue that the unemployed were work-shy because most of them gave the 'lack of suitable work' as the reason for being unemployed. When the 'cannot find any work' response was introduced into the LFS, nearly all of them, as we see above, migrated from the 'suitable work' into the 'cannot find any work' category. Source: Own calculations on September 2004 LFS data set. Earned incomes in households are adjusted by 100 per cent to allow for under-reporting. Income from all sources includes migrant remittances and all social grant income. See Meth, 2006b.

The statement by Marx is either an aphorism (A pithy statement which contains a general truth), or a dictum (A formal pronouncement from an authoritative source. A short statement that expresses a general truth or principle). The statement about justice is probably a maxim (A short, pithy statement expressing a general truth or rule of conduct). It could also possibly be a dictum. The richness (and imprecision?) of the English language leaves one a little breathless at this point. 
simulacrum or representation that a systematic observer constructs when attempting to translate the experience of the poor into images that convey a general understanding of the problem, must always be less than satisfactory - the disjunction between appearance and essence can never wholly be dissolved. ${ }^{6}$ Moving from essence to systematic representation involves the creation and deployment of concepts adequate to the task. Disagreements over the extent and severity of poverty and unemployment in South Africa (and elsewhere) arise because of disagreements over the concepts themselves, and/or the way in which attempts have been made to measure the phenomena they represent. Disagreements arise as well, because of the ways in which the instruments (surveys) designed to measure these phenomena have been executed and/or interpreted.

In a country with a history like South Africa's, the sheer scale of the unemployment and poverty problems adds to the urgency of the need to address them. It adds, as well, to the need to have it made known that government is succeeding in its efforts. Appeals to the patience of the poor on the grounds that eradicating poverty in South Africa is an immense undertaking, ${ }^{7}$ cannot continue to be made indefinitely. The discontent which enduring deprivation exacerbates, is likely to find expression in socio-pathology. Where discontent is widespread, there is always the potential for social unrest. Part of the reason why discontent among those who are poor and/or unemployed is so threatening is because of the unrest that may be unleashed when people who glimpse only the small part of the problem that is their daily life, meet others who share their predicament. This is one of reasons why it is important not only to succeed in the struggle against poverty, but also to make that success known far and wide.

Doing justice (like addressing poverty), and having it seen that justice has been done, is a political process. Stung by a barrage of criticism, ranging from accusations of having surrendered to international capital's neo-liberal agenda, to a frequently expressed dismay at the corruption and incompetence of the civil service, and to not infrequent outbursts of civil unrest, the country's political elite needs constantly to be reassured that it has been successful in improving the lives of many of the poor, and that success in countering the

6 To recognise the distinction between essence and appearance is to take but the first step in a scientific inquiry. The further one goes, the tougher it gets. Anyone who doubts this should sample something like Tony Lawson's Economics and reality (1997), where they would be obliged to begin thinking about the unsynchronised nature of the three domains of reality, "... namely the empirical (experience and impression), the actual (actual events and states of affairs in addition to the empirical) and the real (structures, powers, mechanisms and tendencies, in addition to actual events and experiences" (p.21, emphasis in original)) 
continued suffering of the many millions still to be reached by policies intended to improve their wretched lives, will not be long in coming.

In this intensely charged climate, any suggestion that government is failing in its mission to solve the poverty and unemployment problems, is unlikely to be welcome. A recent incident, typical of its kind, illustrates the reception a claim of that sort is likely to receive. John Pilger's book called Freedom Next Time, published a short while ago, is not terribly polite about South Africa's achievements in the field of poverty and inequality reduction. The book excited comment at the very highest level - no less a personage than the Minister of Finance saw fit to respond to it. It is not the purpose of the present paper to consider what these two protagonists had to say, ${ }^{8}$ rather, it is to focus on three issues that arise out of another response to Pilger, this one by Joel Netshitenzhe, head of the policy unit in the Presidency. It appeared on the same page as Pilger's response to the Minister of Finance in the Sunday Independent, under the headline "Voters do not share Pilger's perception". This has underneath it, a somewhat lurid strap that reads "Journalist has distorted facts to suit his ideology and fails to acknowledge the immense changes that have taken place since $1994 "{ }^{9}$

Two of the issues arising out of the Netshitenzhe piece are empirical matters. The third issue, referred to briefly above, is that of government's propensity to clutch at straws in defence of its anti-poverty policy. One of the empirical matters concerns the relationship between unemployment and changes in the participation rate, and government's persistent misinterpretation of the record, a question I have addressed a couple of times in the past (Meth, 2004; 2005). The other is about two sets of estimates of the progress of the struggle against poverty (van der Berg et al, 2005; Meth, 2006a and 2006b) currently doing the rounds.

For all the torrent of words spewed out by government on poverty, there is no coherent document that says - "this is what we believe the extent of the poverty problem to be and this is how we intend to tackle it. Oh! and by the way, here is our progress report for

\footnotetext{
$8 \quad$ Pilger seems to have started the ball rolling with an article that appeared in the Sunday Independent of July 302006 , under the heading "Reich is in the shadows, but still in control". The Minister of Finance's response, with the headline "Pilger loses the plot in quest for drama" appeared in the Sunday Independent of August 13 2006. Pilger's reply to the Minister was run in the Sunday Independent, August 202006 (" 'Moribund' social spending is holding back the marginalised majority"). it had distanced itself from what is merely Netshitenzhe's opinion. Similar considerations apply, of course, to the headline above the Pilger piece on the same page.
} 
the past $n$ years, with quantities adjusted for quality." ${ }^{10}$ A plethora of poverty alleviation programmes, some generously funded, has achieved less than its potential. This can probably be ascribed, as Swilling et al note, to something that:

“... most economistic and reductionist analyses fail to address, namely the complex and challenging task of institutionalising developmental state institutions. Measuring inputs (expenditures) and outputs (delivery), bemoaning the impacts (rising poverty) and then blaming the macro-economy", they continue, "ignores the quintessential message of institutional economics; namely that financial flows are mediated by institutional transactions that are time bound, constrained by human capacity and costly. If these institutional arrangements are inappropriately configured and/or are rendered ineffective by dysfunctional power relations, inadequate capacity and/or corruption, expenditures will have limited impacts. It follows therefore, that spending more via dysfunctional institutions could result in qualitatively poorer outcomes than spending less via functional institutions." (2005, p.4)

Attempting to demonstrate that the claims made in the statement cited above, are true would take us well beyond the limits of the present paper. In any case, the bucket loads of money slung into child support grants, much of which appears to have been on target, makes it highly unlikely that poverty worsened in the period after 2001 . The goal here is more limited, namely, to show that the state, not content with the modest improvements in people's welfare caused by the extensions to the social protection system, exaggerates the extent of the improvement. Obviously, to substantiate the claim that the South African government is addicted to good news, it is necessary to demonstrate that progress reports exaggerate actual achievement.

We begin with an examination of the conceptual status of the various claims made in the debate over poverty. After that, we glance at some of the forces acting on the South African state as it attempts to go about the business of formulating and implementing anti-poverty policy. The discussion on concepts, which will be used to open the

10 The AsgiSA (Accelerated and Shared Growth Initiative for South Africa), does little to encourage the belief that those responsible for drafting the programme have a real understanding of how difficult it is to 'share' the benefits of economic growth. The programmes in the AsgiSA talk of hundreds of thousands when they should talk of millions. 
proceedings, begins with a consideration of the distinction between 'facts' and 'artefacts'. ${ }^{11}$

A blurring ${ }^{12}$ of this distinction, it is argued, is, if not a necessary, then certainly a very useful part of the post-apartheid state's defence against critics who claim that it is not making sufficient progress in the war against poverty.

11 Artefact: Something observed in a scientific investigation that is not naturally present but occurs as a result of the investigative procedure. (Oxford English Dictionary) Reversion to the authority of the dictionary here should be seen for what it is - the uncertainty of one who works with words, of precisely what certain words actually mean, as opposed to what one thought they meant (hence the brief exploration above of the nuances of aphorism, maxim and dictum).

12 Writing is fun. Rereading the sentence containing the verb 'blur', it occurred to me that it was necessary to specify whether 'blurring' was viewed an act of omission, or one of commission. The Oxford English Dictionary says that 'blur' is "make or become unclear or less distinct", thus allowing for both possibilities. Since it is unlikely that government spokespersons even make a distinction between fact and artefact, the sin must be one of omission. 


\section{2. 'Facts', Artefacts and Anti-Poverty Policy}

That Netshitenzhe finds Pilger's views disagreeable (as indeed they are) is clear. In his response Netshitenzhe considers 'invective', and 'rubbishing' or 'flaying' Pilger's work. Instead of indulging himself in any of these relatively unproductive pursuits, he declares his intention of tackling Pilger on the 'facts'. Acknowledging Pilger's right to hold contrary views, he says:

"There is nothing wrong in holding such views. The problem is when facts are distorted to argue a profoundly ideological predisposition."

Consistent with this approach, most of the remainder of the Netshitenzhe piece is devoted to an examination of "Pilger's assertions on just three issues: poverty, the social wage and unemployment." Proceeding in calm and measured tone, he unrolls a series of 'facts' in support of his argument that:

\footnotetext{
“... the problem with his [Pilger's] treatise is that he gets the facts wrong, and very wrong. Quite clearly, moving from his ideological standpoint, Pilger set out to find a democratic revolution betrayed, and he found it."
}

The piece ends as politely ${ }^{13}$ as it began, with a: “... what we do request from him [Pilger] is: the facts, next time!"14 (Sunday Independent of August 20 2006).

What we have here is a classic case of an individual seeing the mote in someone else's eye while missing the beam in their own. Netshitenzhe's 'examination of Pilger's assertions' is a mixture of facts, (selected) artefacts and unsupported assertions. It is important to distinguish between them.

\footnotetext{
13 Pilger does not regard Netshitenzhe's piece as polite. In his reply to Netshitenzhe ("ANC government has yet to free citizens from fear of poverty", Sunday Independent, September 10 2006) Pilger says that Netshitenzhe "resorts to ridiculous abuse"

14 The comrade Netshitenzhe is much enamoured of facts. In the Background chapter of $A$ nation in the making, (of which work he, if not the author, is certainly one of the parents) one finds the following statement: "The methodology used in this analysis is premised primarily on facts and figures. In this regard, the document avoids the temptation to allow a priori prejudices and beliefs to sully an objective appraisal of social dynamics, with the hope - and, the conviction - that the facts will speak for themselves." $(2006, p .8)$
} 
When the Department of Social Development says that it has paid out 4309772 million child support grants in the month of April 2004, the statement may (potentially) be verified by means of the paper trail in its wake (the relevant administrative records). If, after, auditing, these records are found to have been properly constructed, we are on reasonably safe grounds if we describe the claim by the department to have made that many payments as a fact. ${ }^{15}$

As soon, however, as anyone ventures into the interpretation of what such facts might mean for poverty, they exchange the security of the verifiable for uncertainty of the artefact. It were a good thing if everyone recognised that results pulled out of survey data by social scientists are not 'facts'. They are artefacts, which may, if they are well constructed, allow glimpses of a complex reality.

When a social scientist says, as I do below, that the child support grants raised such and such a number of people out of poverty, that is an artefact. ${ }^{16}$ Its 'truth', if it embodies any, depends on many other factors, starting with the concept of poverty, and proceeding through such questions as to whether or not the survey from which it is drawn has been competently designed and administered, and whether or not respondents have been truthful. Finally, the survey results have to be raised to a population total, so the 'truth' of the statement depends as well on whether population figures are correct.

Sliding from the insecurity of artefact into unsupported (or barely supported) assertion, Netshitenzhe proclaims that:

"... [we] are on course to meet - the target of halving unemployment and poverty by $2014 . "$

Extrapolated from artefacts, some of which are given in his 'examination of Pilger's assertions', neither claim is supported by the alternative interpretations of South African reality offered below.

15 Henceforth, when this word is used without scare commas it will refer to (potentially) verifiable statements of the type used in the illustration.

16 Strung together in a sequence, artefacts are used to create interpretations. Sometimes the rigour or otherwise of such constructions can be ascertained using, for example, statistical tests. Much of the time, however, competing interpretations of the world can be created from the same facts and artefacts. The major disagreements between economists (the paradigms to which they belong) are one result. See Cole, Cameron and Edwards (1991) or Part 1 of Byrne (1999) for an exposition of these disagreements. The discussion by Lal and Myint (1996) of 'forensic story-telling' provides a good introduction to the difficulties of "choosing amongst a number of competing stories the one which fits the 'facts' better than another" (p.5, scare commas in original). 
Careful readers of the original article will also note that Netshitenzhe engages in selective use of the artefacts in his two primary sources, van der Berg et al (2005) on poverty, and Bhorat et al (2006) on the social wage. ${ }^{17}$ So, not only does Netshitenzhe not follow his own advice and stick to the facts, he also does not draw reader's attention to artefacts in his chosen sources that take the shine off his glowing presentation of his government's achievements.

The question is: why does government's most senior spokesperson, outside of Cabinet, find it necessary to offer evidence of progress which he knows to be contested, and which he must know, will be criticised when it is used? Before setting out to find an answer to this question, it is as well to acknowledge that any explanations offered will, of necessity, be both speculative and fragmentary - it is impossible to tell the whole story.

The quest begins with a consideration of one of the ways the ANC in government responds to criticism. It is clear that certain criticisms strike a raw nerve, exciting what may seem to onlookers, a disproportionately vigorous response. One of these criticisms, which Pilger makes, ${ }^{18}$ is that the policies of ANC in government are 'neo-liberal'.

For critics, the use of labels can be economical, insofar as they make it possible to invoke, with admirable brevity, a response to a web of policy measures. Using labels against the wielders of power is also satisfying, especially if the labels are a reasonably accurate description of the conduct in question. Adopted as political slogans, labels can help to create countervailing power. The neat label of neo-liberal, while capturing aspects of the reality of South African economic and social policy, is too limiting, however, to be used exclusively to describe a complex, messy politics. As Seekings (2002) has pointed out: "... the democratic state inherited a highly redistributive budget from the late apartheid state in 1994" (p.5). To describe all the steps taken since then to address the conditions of the poor (regardless of their success) as 'neo-liberal' is not useful.

$17 \quad$ Netshitenzhe mines Bhorat et al piece for the most spectacular-sounding achievements in the asset provision field. He fails to mention their finding that asset poverty reduction appears to have been more rapid between 1993 and 1999 than it was between 1999 and 2004. Nor does he mention their conclusion that the relative headcount reduction in the bottom decile was much lower than that higher up the distribution (2006, p.33). Netshitenzhe also does not draw the reader's attention to the continuing "marginalisation of poor African women living in rural areas" where Bhorat et al discover the asset poverty headcount rates in 2004 to have been above those in 1993 (2006, p.31). marginalised majority", Sunday Independent, August 20 2006, says that: "It is a fact, alas, that Manuel has opted for neo-liberal growth strategy which is ideological, and that real growth that would benefit the majority has been anaemic. By any measure, it is a false strategy in the war against poverty and indignity. The majority of South Africans, who saw off apartheid, deserve better." 
The recent research report into government's approaches to poverty and development policy (referred to above) by Swilling et al (2005), argues that the South African state has followed neither "the classic neo-liberal state model, nor the developmental state model" (p.16). They try to make sense of the messiness of policy by focusing on the search (by government) for the 'elusive developmental state' during the first democratic decade, and into the second, where the search intensifies $(2005$, p.6). Parts of their analysis seem facile, ${ }^{19}$ but they are certainly no apologists for the state. In any case, one need not swallow their whole analytical apparatus. To the uninitiated, the 'developmental state' may sound cuddly. For those without knowledge of the forebears of this state form Swilling et al spell out the characteristics of the 'classic developmental state'. It has the "following elements:

- a 'determined developmental elite' committed to the modernisation project; 'relative autonomy' from major capitalist economic interests who are always keen to capture the state;

- 'a powerful, competent and insulated economic bureaucracy' that enjoys the highest possible political support but operates without too much political interference;

- a 'weak and subordinated civil society' which means there are no rival centres of alternative policy formation;

- the 'effective management of non-state economic interests' via formal structured compacts, incentives and penalties; and

- accessible and usable institutions of 'repression, legitimacy and performance' "20

In an era in South Africa where the discourse of policy formation was generously sprinkled with calls for 'transparency' among 'stakeholders' in finding the 'way forward', open acknowledgement of a desire to see the third of these preconditions met would not have

19 For example, where they speculate on the possibility that black economic empowerment (BEE) and broad-based black economic empowerment (BBBEE or BBEE) “... will manage to break white control of investment decision-making quickly enough to ensure that private sector investment levels climb back up over the 15 per cent of GDP mark" (Swilling et al, 2005, p.74). No reasons are offered as to why black capitalist behaviour should differ from white. 
been politically advisable. The preferred kind of developmental state (at least in public discourse) would have been what Swilling et al term the 'pragmatic' developmental state. Such a model would:

“... look for a leading developmental role for the state (with a focus on human capacity, knowledge and skills), but via creative and complex partnerships with non-state actors (especially the ethical and responsible wings of the corporate sector), and with civil society formations rooted in poor and working class communities in particular." (2005, p.15)

This vision may (or may not) have been in the minds of those thinking about development policy in the first development decade, but, argue Swilling et al:

"... there is a lot of evidence that key thinkers in the South African state who are leading the post-2004 'developmental state' perspective are using a 'classic developmental state' model." (2005, p.15)

Whatever the case, the fledgling state could not match word and deed. As Swilling et al observe:

"Despite aspirations to be a developmental state, the necessary capacity for purposive, decisive and autonomous policy coordination was not successful prior to 2004, despite various attempts." (2005, p.16).

The reality was one of a desperate scurrying to fill posts, write reports and compile budgets, forcing many: 
“... progressives in government to make a trade-off between no progress in achieving broadly defined transformation goals, and achievable more narrowly defined short term strategic advances." (2005, pp.16-17)

Their conclusion on the upshot of this 'muddling through' is worth citing at length:

" 'Policy choices' during the first decade of democracy in South Africa", they argue, "were based on what was invariably an imperfect and incomplete reading of a complex reality (including the balance of class forces), after which choices were made under extreme time pressures and developed their own relatively autonomous momentum as they got 'sold' to many diverse constituencies to mean different things - hence the (suspect and dangerous) assumption that the more bland a policy document was, the wider the support base would be. What often started off as a half-baked idea at a pressurised meeting must suddenly be packaged by desperate (and quite often ignorant) political leaders to win stakeholder support by government officials and advisors who were often plagued by doubt and / or shallow mandates. But often it was too late to reverse the process and all that could be done was to pretend that this was all part of a well-conceived plan." (Swilling et al, 2005, p.18)

This, of course, is only a set of generalisations (hypotheses) about the way in which policy formation took place in South Africa's first decade of democracy. ${ }^{21}$ As far as aspects of anti-poverty policy are concerned, it has about it, the ring of truth. Clearly, however, it does not apply to all policy. Equally clearly, it alone cannot explain the shape of the policy whose results Netshitenzhe seeks so vigorously to defend. It is merely one part of the story, another part of which is related by Friedman (2006), one which is brought to mind by the following statement from the Netshitenzhe piece:

21 Among the more obvious candidates for the award of the title of most 'half-baked' policy is the Expanded Public Works Programme (EPWP), in its guise as filler of the chasm in the social protection system, said chasm being the absence of any other social protection for all people of working age not protected by the provisions of the Unemployment Insurance Act. As a scheme for providing some small number of the unemployed with employment while at the same time creating infrastructure, it is commendable. As a means of bolstering social services, it is laudable. As a substitute for proper social security, it would be laughable, were it not so pathetic. 
"Pilger", he says, "concedes that his treatise is not meant to "suggest that people fail to recognise the achievements of the ANC government". How else would he have been able to explain the growing expression of confidence in government's programmes

during successive elections since 1994?" (Sunday Independent August 20 2006) $)^{22}$

Netshitenzhe's leap from increasing support for the ANC to a "growing expression of confidence in government's programmes" may not be made without analysis of the reasons why voters voted the way they did (i.e., it is an unsupported assertion). Steven Friedman's piece supplies an answer to the question Netshitenzhe asks of Pilger - and the answer is: identity voting. The argument is that (among some significant sections of the population?) the "... chief rationale for voter choices is who voters believe they are and their assessment of which party can best provide a vehicle for who they are" (Friedman, 2006, p.5). ${ }^{23}$

There are both strengths and dangers to identity politics. One of the latter is the ease with which criticism of government is "dismissed as evidence of prejudice" (p.6). Friedman argues, however, that the constraints of identity politics are:

“... less remarkable than the fact that government politicians do continue to feel the need to respond to media criticism or the views of white-led civil society organizations. This is the consequence not of strategic calculation but of a particular racial dynamic. Postapartheid politics has been under-pinned by a theme, often not stated overtly, which is pervasive; whites expect a black government to fail and the leaders of that government know they do. It is, therefore, a key preoccupation of much of the new governing elite to demolish these assumptions by demonstrating that black people can govern an industrialized society with a complex market economy. Indeed, the central preoccupation of the post-1994 administrations has been to prove white racism wrong." (Friedman, 2006, p.6) 
This preoccupation, Friedman argues, “... weakens the quality of democracy by prompting enthusiasm for technical and managerial solutions ${ }^{24}$ rather than for democratic broadening or deepening." (p.6)

Although they approach the question from different angles, the arguments presented by Swilling et al (2005) on the one hand, and that offered by Friedman (2006) begin to converge around a story of a new elite, anxious to show that it will solve the poverty problem its way. The aspirant developmental state that they lead lacks, however, some of the key elements of the classic developmental state, necessary to solve the poverty problem by 'technical and managerial' means. Not only is its " 'relative autonomy' from major capitalist economic interests who are always keen to capture the state" limited, it also does not dispose of a 'a powerful, competent and insulated economic bureaucracy'. One consequence is the attempted implementation of 'half-baked' anti-poverty policies.

Organisations representing the poor, although vociferous, are not able to ensure that their concerns are heard, with sufficient clarity, by the elite. As Friedman points out:

“... many voters do not enjoy the resources that would enable them to organize to be heard in the public policy debate between elections. Their participation is largely limited to expressing their identities in periodic ballots. Because the poor - about two-fifths of the society - are not heard, their experiences and concerns cannot translate into effective policy. This ensures that they remain mired in poverty and excluded, in a continuing vicious cycle, because participation is largely limited to those with the means to organize." (Friedman, 2006, p.4).

To defend election campaign rhetoric like the ANC's 2004 manifesto "A people's contract to create work and fight poverty", government must needs be selective in its use of such information as is available. Since much of it is critical of government's attempts

24 Swilling et al make the point that under the stressful conditions of the first decade of policymaking, "many discourses were adopted from international experiences heavily influenced by the interests of donors who funded study tours (eagerly seized by overworked officials needing a welcome break from the office to think and reflect), and technical advisors who tended to frame the questions in the language of the day (what Stiglitz has called the 'roaring nineties'), namely a kind of technocratic neoliberalism devoid of liberalism's own original moral humanism and unsubstantiated by a rigorous theory of justice" (2005, p.17). As an example, government enthusiasm over public works, even if it does not have its origins in World Bank proselytising about the wonders of what it called 'workfare' as the preferred form of social security in developing countries, was probably positively influenced by the Bank's viewpoint (see World Bank, 2001, pp.155-156 and 167). 
to address poverty, an adherence to the principle of audi alteram partem (hear the other side) could undermine an otherwise plausible account. It is for this reason, I suspect, that Netshitenzhe uses the poverty figures published by van der Berg et al (2005), rather than the much less optimistic figures I have produced (Meth, 2006a). ${ }^{25}$ In short, to defend the barely defensible, Netshitenzhe is obliged to resort to selective presentation of facts and artefacts; to unsupported assertion; and where unemployment is concerned, as we shall see below, to misinterpretation of (dubious) artefacts.

As almost everybody recognises, the ANC government deserves praise for a number of very important achievements. It is not backward about coming forward to hear these praises sung. More is the pity then, that its appetite for praise is not matched by an ability to accept criticism for the failures over which it has presided. High on the list of these is the failure to devote sufficient resources to the task of monitoring its attempts at redressing poverty. Government support for research into poverty and inequality, South Africa's most pressing problems, is miserly.

Government needs to summon up the courage and the humility to face its diverse critics, without recourse to routine defensiveness of the sort displayed by Netshitenzhe in his response to Pilger. From all walks of life in South Africa, these critics express their dismay with perceived policy failures. They do so in a wide variety of ways, from violent demonstration to econometrics-heavy scholarly work. It needs to be recognised that many of the whites who engage critically, do so not with the expectation that the black government will fail, but with the profound hope that it will succeed. Believing, as Friedman argues, that the voices of the poor are inaudible (or if audible, are so only through a filtering system that removes undesirable 'noise'), they throw their energies into creating the artefacts and speculations that approximate the voices of the poor. Aware that this is not the same as the authentic voices themselves, they urge government to be less dogmatic, less convinced of its superior knowledge, as it goes about the business of policy formation and implementation.

What some of the authentic voices articulate on occasion, does not make for pleasant listening. Lacking the capacity for sustained protest on a systematic (and possibly more orderly) basis, communities or relatively small groups of individuals within communities,

25 Netshitenzhe may not have been aware of the existence of my estimates. Senior officials from the Presidency, however, certainly were. Two of them were present at a workshop held in the HSRC offices in Pretoria on $17^{\text {th }}$ February 2006, at which our respective results and methodologies were aired and critically evaluated by Professors Lam (my work) and Leibbrandt (that of van der Berg et al). Neither of the sets of estimates on offer was accepted by the workshop participants as definitive. 
respond to continuing deprivation with protests that frequently turn violent. An upsurge of these incidents in recent times suggests that the patience and restraint shown hitherto by the poor may be giving way to greater activism. ${ }^{26}$ This activism, around issues such as "lack of housing and sanitation, electricity and water cutoffs" has seen communities rejecting attempts by political leadership (local and national) to lower social tempers. ${ }^{27}$ Children are occasionally at the forefront of such actions. A particularly ghastly incident of this sort occurred in August 2004. A report under the headline "Twenty children shot in Harrismith protest" described how 4500 children, protesting about service delivery, streamed onto the national highway, leaving the police, according to a spokesperson, with no alternative other than shotgun pellets to disperse them. ${ }^{28}$ Incidents of this type are, thankfully, relatively rare - the bulk of the protest action seen in recent years in South Africa, appears mainly to involve adults (or, at least, children do not feature prominently in the reports).

It is interesting that Netshitenzhe, in his response to Pilger, chose to 'prove' the ANC's continuing, indeed growing popularity among the population, by reference to election outcomes. If he had chosen instead, to use the results on "The views of the public" in Chapter 4 of the Ten Year Review (PCAS, 2003, pp.91-95), he would have found the going a little harder. Presenting results from the Institute for Democracy in South Africa's (Idasa) Afrobarometer, and from Markinor (a private-sector marketing information organisation that conducts opinion polls), the Review celebrates a general improvement

26 A list of protest actions, drawn from just one newspaper, the Weekly Mail \& Guardian, gives a flavour of the mood among sections of the poor. Service delivery failures feature prominently among the causes of the disturbances. "March draws attention to plight of homeless", Hila Bouzaglou, 20 September 2006. "Khutsong: 'The ANC sold us' ", 22 February 2006. The report says that: "The cause of unrest is economic. People are fed up waiting for jobs and basic services such as electricity, clean water and sanitation." "Eleven arrested in North West service protest", 23 January 2006. "Three injured in southern Cape service protest", 16 January 2006. In this instance: "police threw stun grenades and fired rubber bullets at protesting Power Town informal settlement residents". "A winter of discontent", Marianne Merten, 27 May 2005. This article contains a catalogue of the incidents in the first five months of the year. Although the list of incidents in the Merten article is long, President Mbeki was still able to argue, and not implausibly, that as yet, "urban unrest over service delivery" has not yet reached the point that would suggest that the country is threatened by the "centrifugal tensions" that have caused collapse elsewhere in Africa. He claimed further that neither these demonstrations nor minority mobilisation present "any immediate danger to our democracy" (Urban unrest could lead to conflict, says Mbeki" (Mail \& Guardian, 25 May 2005, online version).

Growing community assertiveness is not entirely unexpected. Writing a few years ago, Good (2001, p.47) pointed out "the extent of the demobilization in South Africa should not be exaggerated" in spite of the "... systematic (and astonishingly rapid) process of political demobilization... " that took place after 1994, which left many of the institutions of civil society that represent the poor in a weak state. Some commentators are quite upbeat about the potential of groups representing the interests of the poor. See for example, Desai (2002), or the article by Raj Patel and Richard Pithouse, that appeared in Mail \& Guardian May 20 to 262005 (pp.30-31) under the headline "Epidemic of rational behaviour". poorly-housed can succeed before "other festering problems adding to the explosive mix" result in major confrontations. The article from which these comments are drawn, by Linda Ensor, appeared under the headline "Protests signal that the patience of SA's poor is wearing thin" in Business Day, 31 May 2005, online version. 
in views (and not unreasonably so), but acknowledges the persistence of some severe problems. The Review says that:

"... the overwhelming majority felt that unemployment was the major challenge for the next decade, followed by addressing health and crime problems. Significantly, poverty and the provision of services were ranked as lesser challenges in the next decade." (PCAS, 2003, pp.94-95)

Public opinion, as is well known, can be fickle. It is certainly difficult to ascertain with reliability (pollsters regularly forecast election results incorrectly). Not only that, some views, when reliably ascertained, are not always easy to understand. Does the relative lack of concern about poverty expressed above (obtained at a time when the reductions in poverty brought about by extension to the social grant system were barely noticeable) mean that people have subsumed poverty into lack of employment, reasoning that if only they could obtain work, poverty would not be a problem? The Ten Year Review shows significantly reduced concern over education and health services in South Africa. Indeed, when one delves into the General Household Surveys, the 2005 GHS, for example, one discovers that the levels of satisfaction reported after attendance at a health facility (public or private), were very high (88 per cent were either very satisfied or somewhat satisfied). This holds even among the very poor, most of whom would have used the public health system, parts of which are notorious for their appalling service. The rating 'very satisfied' was lowest among the poor (about 62-69 per cent). It rises as income does, to about 8788 per cent among the moderately well-off (monthly per capita expenditure in excess of R1200 per month), then falls to about 73 per cent among those spending more than R10 000 per capita per month. ${ }^{29}$ Presumably, the very well-off are more demanding, while many of the very poor do not receive good treatment. ${ }^{30}$

Reference has been made above to Netshitenzhe's use of the flattering parts of the Bhorat et al (2006) paper of shifts in access to services and assets. A less flattering part of the story is told, not by Bhorat et al, but by estimates of what it is the poor find to be unsatisfactory about service (or asset delivery). To illustrate, we turn to the education and

29 Source: Own calculations from GHS 2005 data set

30 Glennerster and Hills ask why, despite "... improved educational outcomes, improved housing standards, better performance by the National Health Service, more redistribution towards the poor" in the UK, "... there is so much dissatisfaction with the state of welfare?" (1998, p.2). The answer, rising consumer expectations (of high standards) caused by the fact that the non-welfare world has not stood still (rising real incomes). In short, an improvement in service delivery does not translate automatically into an increase in approval ratings. 
health data in the 2005 GHS. First, some figures on problems at school. From a list of half a dozen problem areas identified by the GHS, data on four of them have been extracted, by per capita monthly expenditure levels. A minority of scholars (learners in newspeak) report 4.9 million grievances about their school experience. These are listed in Table 1, which sorts the complainants into two categories. First are those in households where per capita expenditure was below the R319 per month. This is roughly R250 per capita per month in 2000 prices, the poverty line used in van der Berg et al (2005). The second category captures everyone below R412 per month, which is roughly R322 per month in 2000 prices, the poverty line used in Hoogeveen and Özler (2004). ${ }^{31}$ These poverty lines are referred to as PL1 and PL2, respectively, in the table.

Lack of books (in July, when the school year begins in January or February?), followed by poor facilities, account for most of the problems faced by scholars. The number suffering poor teachers is, however, not trivial, and the number with no (or too few) teachers is less trivial still. The most striking, and probably least unexpected feature of the results is the preponderance of the poor among those experiencing problems at school. The figure of 4.9 million does not represent that number of different individuals, each experiencing one of the problems. Nevertheless, a very large number of different individuals (several million) is involved - half of them (2.44 million) reported one problem only. The largest number of shared problems (536 000) experience a lack of books, in facilities that are in bad condition. The next most common combination of problems was among the 389000 scholars, plagued by a lack of books and teachers. Apart from pointing to a fertile breeding ground in which resentment can transmute itself into a variety of social ailments, these results suggest that boasting about the pro-poor nature of service delivery is not wholly justified.

31 In Meth (2006a), I checked to see that reported expenditure did not exceed reported income by more than one expenditure category. In all cases where expenditure was greater than income, expenditure was adjusted upwards to shift it into the same category as income. This crude imputation exercise, which I called 'purging' has not been performed here. The numbers of people counted above as suffering various inconveniences will, therefore, be overstated. A rough check of the numbers against per capita incomes suggests that the effect will not be excessive. Unfortunately, since the GHSs do not collect information on migrants, they too, understate poverty. To counteract this, the income figures used in this paper have been adjusted upwards so that survey and national accounts income totals are roughly equal. 
Table 1: Numbers of Scholars Reporting Problems of Various Sorts at School - July 2005

\begin{tabular}{lrrr}
\hline & No. below & No. below & \\
& R319/month & R412/month & \multicolumn{1}{c}{ Total } \\
\hline Lack of books & 1988000 & 2116000 & 2405000 \\
Poor teaching & 462000 & 494000 & 584000 \\
Facilities in bad condition & 1038000 & 1071000 & 1190000 \\
Lack of teachers & 579000 & 621000 & 722000 \\
Total & 4067000 & 4302000 & 4901000 \\
Percentages below PL1 and PL2 & 83.0 & 87.8 & \\
\hline
\end{tabular}

Source: Own calculations using 2005 GHS data set

Unlike school, where attendance is compulsory, people who are unwell are not obliged to seek medical help. During the reference month for the 2005 General Household Survey (June 2005), 5.9 million people who reported being ill or injured. They may be divided into those who sought attention (4.8 million people) and the remainder, who did not. The 1.08 million people who did not receive medical attention, may be sub-divided into those who said that it was unnecessary to attend a medical facility (681 000 people), and those who needed medical attention but were unable to obtain it. Among this group of 392000 people, who, it may be assumed, deemed that they did want or need medical help, 83000 did not receive it because the nearest medical facility was too far away, and 208000 because it was too expensive. ${ }^{32}$ In other words, if the reference month was a typical month, then it is possible that during the year, about three million people would have been denied medical attention because they were too poor.

The quality of help they receive in public sector clinics varies enormously. Although the bulk of users report being satisfied, a large number of people experience problems. An indication of the type and extent of problems may be obtained from the GHSs. Table 2 lists the numbers of individuals who reported experiencing one of four problems with the quality of service provided at public sector clinics during the reference month for the 2005 GHS. They are divided once more into two groups, this time into the group individuals with per capita expenditure of less than R412 per month in 2005 prices (R322 in 2000 prices, the possible lower bound of South Africa's poverty critical range); and those with per capita incomes below R824 per month, a figure that is not much higher than the upper bound of R760 per month.

32 It is not clear why so many people report that care was too expensive. As Blecher and Harrison point out, primary health care (at least) is free at point of service $(2006, \mathrm{p} .32)$. 
Table 2: Numbers of People Reporting Problems at Clinics during June 2005

\begin{tabular}{lcrr}
\hline & $\begin{array}{c}\text { No. below } \\
\text { R412/month }\end{array}$ & $\begin{array}{c}\text { No. below } \\
\text { R824/month }\end{array}$ & Total \\
\hline Facility not clean & 24400 & 39000 & 104400 \\
Long wait & 150900 & 298200 & 872200 \\
Drugs needed not available & 60100 & 121000 & 329800 \\
Staff rude, uncaring, patient turned away & 45200 & 80400 & 221900 \\
Total & 280600 & 538600 & 1528300 \\
\hline
\end{tabular}

Source: Estimated from 2005 GHS data set.

The number of people inconvenienced during the course of the year depends on two things; whether or not the figures are typical of any month in the year, and the frequency of visits of individuals who are inconvenienced. If the figures for the month of June 2005 are typical for those of the year, then there would have been about 10 million episodes during the year where people were made to wait too long for medical attention. Likewise, there could have been about four million episodes in which people did not get the drugs they needed, and nearly three million episodes where people will have experienced rudeness or uncaring attitudes from staff, or having been turned away from the facility. Roughly one-third of all of these problems would have been experienced by poor people.

This account squares with the report by Blecher and Harrison that in primary health care (PHC) facilities, "quality of care is sometimes sub-optimal, public facilities often have long waiting times and primary care facilities tend to have few doctors" (2006, p.32). Comparisons between service provided in the private sector and public sector are stark: as opposed to the 46 per cent who complained about too long a wait at public sector clinics, about ten per cent of those who saw private doctors made a similar complaint. In public sector clinics, the necessary drugs were not available to about 18 per cent of patients; three per cent of those consulting a private doctor made the same complaint. Less than two per cent of those attended to by private doctors complained that staff were rude and uncaring, as opposed to the almost 12 per cent who made this complaint about service at public sector clinics.

The GHS does not ask people what service they would choose if income were not a constraint. It looks as though about 130000 people with per capita incomes less than R412 per month chose to make the sacrifice involved in consulting a private doctor. This is close to half of the number (303 000) in similar circumstances who chose to use a public sector clinic. Voting with one's feet when one is so poor is possibly the strongest criticism 
of the system that one can make. Despite the obvious progress in making health care available to more South Africans, especially among the poor, there apparently remains considerable scope for reduction of inequalities between the quality of publicly- and privately-provided health services.

Whenever a politician or senior civil servant feels the urge to boast about how far we have come since the bad old days (as undoubtedly in many respects we have) or, more worryingly, expresses a need to involve the intelligence services in a search for explanations of why the poor sometimes behave poorly, they would do well to consider the burdens discussed above, none of which their exalted status now allows them to experience any more. 


\section{Misunderstanding Unemployment}

Repeated criticism of South Africa's unemployment statistics suggests an unwillingness, on the part of government, to engage seriously with the problem. Nowhere is this more apparent than in the refusal by the Presidency to pay attention to the story told by those statistics. Instead, various officials in that august office reproduce, at regular intervals, a story dreamed up to explain the growth in the number of unemployed. It surfaces once more in Netshitenzhe's response to Pilger. In essence, the tale is that the number of unemployed has grown faster over the medium term (1997-2005, in the version below) than the number of employed because the participation rate (the total of those working or wanting to work divided by working age population) outstripped growth in the working age population. ${ }^{33}$ Netshitenzhe puts it this way:

"Since 2001, job creation has grown at the pace of 350000 a year.

For the period 1997 to 2005 , the labour force participation rate (i.e. the ratio of economically active adults to the total working age population) increased from 45.3 percent to 56.5 percent. This reflected a growth rate of more than 4.8 percent a year in the economically active population (from 11.4 million to 16.7 million) during a period in which the population growth rate was about 2 percent a year.

Only part of the growth in the economically active sector can therefore be ascribed to population growth and the rest is a result of greater numbers of people, especially women, defining themselves as looking for work."34 (Sunday Independent, August 20 2006, emphasis added)

33 In addition to pointing out in person to senior Presidency officials, that this story is not true, I have, as noted above, also published three articles that show why it is wrong (Meth, 2004; 2005 and 2006c).

34 This (suspicious) statement is interesting, drawing attention, as it does, to the difference between the act of 'defining oneself as looking for work' (appearance) and actually being unemployed (essence). 
The sources of this story are the October Household Surveys for the period 1997-1999, and the Labour Force Surveys for the period from 2000 onwards. The relevant figures are reproduced in Tables 3, 4 and 5. Let us use the information they offer to deal with his interpretation of labour market developments. To be pedantic, job creation, on the basis of the LFS figures, was not 350000 per annum in the period 2001-2005, it was about 300 000. ${ }^{35}$ More importantly, though, Netshitenzhe could also have pointed out that by 2005, according to the figures in Table 4, employment had recovered its 2000 level. Endpoint selection to embellish a weak argument is not a good idea. ${ }^{36}$

Two factors contribute to the rapid rise in participation rates between 1996 and 1999 visible in Table 3. One is an increase of 1.1 million in the number employed, 900000 of whom were in the informal economy. The other is the increases in the numbers of unemployed, 900000 official and 1.3 million expanded. Doubts have been expressed about the validity of both the increases in the numbers unemployed, and in the unprecedented increase in the size of the informal economy. Speculative reduction of employment and unemployment growth to more plausible figures significantly reduces the gap between the growth rate of the working age population, and the growth rate of the economically active, mooted by government as one of the causes of rising unemployment.

35 From Statistical Releases P0210 of 26 September 2005 and 24 January 2006, one may estimate that formal sector employment increased by 141000 per annum in the period 2000-2005, and by 193000 per annum in the period 2001-2005. Corresponding figures for the informal economy, with agriculture removed because of its poor behaviour) were 86000 and 124000 respectively. Totals, adjusted for changes in the numbers of domestic workers and the 'unspecifieds' were 160000 and 291000 respectively. with a 'fact'), because they include the poorly-behaved agricultural employment estimates. 
Table 3: Economic Activity, 1996-1999

\begin{tabular}{|c|c|c|c|c|}
\hline & Oct 1996 & Oct 1997 & Oct 1998 & Oct 1999 \\
\hline Working age population (1000s) & 24700 & 25200 & 25800 & 26300 \\
\hline No. employed (1000s) & 9300 & 9300 & 9400 & 10400 \\
\hline \multicolumn{5}{|l|}{ Official unemployment } \\
\hline No. (1000s) & 2300 & 2500 & 3200 & 3200 \\
\hline Rate (\%) & 19.3 & 21.0 & 25.2 & 23.3 \\
\hline \multicolumn{5}{|l|}{ Expanded unemployment } \\
\hline No. (1000s) & 4600 & 5300 & 5700 & 5900 \\
\hline Rate (\%) & 33.0 & 36.0 & 37.5 & 36.2 \\
\hline \multicolumn{5}{|l|}{ Participation rate $(\%)$} \\
\hline Official & 46.7 & 46.6 & 48.8 & 51.5 \\
\hline Expanded & 56.2 & 57.5 & 58.4 & 61.8 \\
\hline \multicolumn{5}{|l|}{ No. of economically active (1000s) } \\
\hline Official & 11600 & 11700 & 12600 & 13600 \\
\hline Expanded & 13900 & 14500 & 15100 & 16300 \\
\hline
\end{tabular}


Table 4: Economic Activity, 2000-2005

\begin{tabular}{|c|c|c|c|c|c|c|}
\hline & $\begin{array}{l}\text { Sept } \\
2000\end{array}$ & $\begin{array}{l}\text { Sept } \\
2001\end{array}$ & $\begin{array}{l}\text { Sept } \\
2002\end{array}$ & $\begin{array}{l}\text { Sept } \\
2003\end{array}$ & $\begin{array}{l}\text { Sept } \\
2004\end{array}$ & $\begin{array}{l}\text { Sept } \\
2005\end{array}$ \\
\hline Working age population (1000s) & 27900 & 28200 & 28600 & 29000 & 29400 & 29700 \\
\hline No. employed (1000s) & 12300 & 11200 & 11300 & 11500 & 11700 & 12400 \\
\hline \multicolumn{7}{|l|}{ Official unemployment } \\
\hline No. (1000s) & 4200 & 4700 & 5000 & 4500 & 4200 & 4500 \\
\hline Rate (\%) & 25.4 & 29.4 & 30.4 & 28.0 & 26.2 & 26.7 \\
\hline \multicolumn{7}{|l|}{ Expanded unemployment } \\
\hline No. (1000s) & 6400 & 7700 & 8200 & 8300 & 8100 & 7800 \\
\hline Rate (\%) & 34.3 & 40.6 & 41.9 & 41.8 & 41.0 & 38.8 \\
\hline \multicolumn{7}{|l|}{ Participation rate (\%) } \\
\hline Official & 59.0 & 56.3 & 56.9 & 54.8 & 53.8 & 56.5 \\
\hline Expanded & 67.0 & 67.0 & 68.1 & 67.8 & 67.3 & 67.7 \\
\hline \multicolumn{7}{|l|}{ No. of economically active (1000s) } \\
\hline Official & 16400 & 15900 & 16300 & 15900 & 15800 & 16800 \\
\hline Expanded & 18700 & 18900 & 19500 & 19700 & 19800 & 20100 \\
\hline
\end{tabular}

Apart from the questionable nature of the early results, one of the most important features of the Tables 3 and 4 is the unmistakably clear indication they give of the break in labour market statistics caused by the abandonment of the October Household Survey in 1999, and the introduction of the Labour Force Surveys, the first of which was conducted in February 2000 (a pilot in 10000 households). An appendix in the February 2001 LFS (Statistics South Africa 2001, pp.12-13) in the published results explains some of the differences in numbers, but stops a long way short of a reconciliation of the pre-2000 numbers with their counterparts from 2000 onwards.

So obvious is this break that it is worth taking out the figures on either side of it, to see just how large some of the changes are. This is done in Table 5. Some large part of the increase in the number of economically active which Netshitenzhe thinks he detects in the numbers is pure statistical artefact, i.e., it did not occur. Employment in South Africa manifestly did not rise by 1.9 million between October 1999 and September 2000, nor did 
the number of officially unemployed increase by one million. It is ridiculous to suggest that the official participation rate could have jumped by 7.5 percentage points in a single year, or that the expanded rate could have risen by more than five percentage points in the same period.

Table 5: The Break in the Series between 1999 and 2000

\begin{tabular}{lrrr}
\hline & Oct 1999 & Sept 2000 & Change 99-00 \\
\hline Working age population (1000s) & 26300 & 27900 & 1600 \\
No. employed (1000s) & 10400 & 12300 & 1900 \\
Official unemployment & & & \\
No. (1000s) & 3200 & 4200 & 1000 \\
Rate (\%) & 23.3 & 25.4 & 2.1 \\
& & & 500 \\
Expanded unemployment & 5900 & 6400 & -1.9 \\
No. (1000s) & 36.2 & 34.3 & \\
Rate (\%) & & & 5.5 \\
Participation rate (\%) & & & \\
Official & 51.5 & 59.0 & \\
Expanded & 61.8 & 67.0 & \\
No. of economically active (1000s) & & & \\
Official & 13600 & 1600 & \\
Expanded & & & \\
\hline Source: Tables 3 and 4 & & & \\
\hline
\end{tabular}


There have been a couple of attempts to construct a continuous labour market series for the period 1995-2004. ${ }^{37}$ No-one, however, can avoid the fact that the information required to bridge the gap does not exist.

Part of the problem lies with the estimates of the working age population. Year-on-year growth in Table 3 is about 500000 a year, while the Table 4 figures suggest roughly 400000 a year. Whatever the exact number, it is clear that the leap from 26.3 million in 1999 to 27.9 million did not occur. ${ }^{38}$ Nor did the economically active population increase from 11.4 million in 1997 to 16.7 million in 2005, as Netshitenzhe claims. It is possible that growth of the working age population averaged about 1.5 per cent over the period 1997-2005. Growth of the economically active population could have been in the region of 2.0 per cent. ${ }^{39}$ Altering the end-year to 2004 causes this relationship to reverse, growth of the working age population remains near 1.5 per cent per annum, while growth of the economically active population falls to 1.3 per cent per annum. This is because 700000 new jobs, most of them in the informal economy, appeared in the year 2004-2005.40 That single figure is enough to distort outcomes significantly.

It is time to call a halt to this nonsense - the figures not only do not say what Netshitenzhe says they do, they also do not bear out the predictions he makes. He claims, as we noted above, that government and its social partners are on target to halve unemployment (and poverty). Unless one accepts that it is appropriate to predict the future from a single year's results, then as far as unemployment is concerned, there is no evidence to support his 'halving' prediction. His 'analysis' of the relationship between economic participation and unemployment sits awkwardly with his concluding remarks on the matter. Having delivered us of the numbers repeated above, he says that:

37 During the years that the Employment Dynamics Group, put together by Miriam Altman at the HSRC, met (roughly 2003-2005), the question of the 1999-2000 break in the series arose on a number of occasions. Participants, among whom were representatives from the Presidency, could not agree on a satisfactory way of dealing with it.

38 The OHS figures are weighted by the 1996 Population Census, while the LFS figures are weighted by the 2001 Population Census. Inter-censal figures have to be estimated from a model, the results of which exercise are subject to revision. A comparison of Statistical Releases P0302 of 31 May 2005 and 1 August 2006, which contain the mid-year population estimates for 2005 and 2006 respectively, reveals some very interesting changes in the estimated population growth rates. period. It also assumes that the participation rate in 1999 was the same as it was in 2000. If one subtracts from the values for prior years, the absolute percentage changes observed in the 1996-1999 series, one arrives at a participation rate of 54.7 per cent in 1997. Multiplying the simulated 1997 working age population ( 26.55 million), by the simulated participation rate, yields an economically active population of 14.5 million, not the 11.4 million that Netshitenzhe finds.

40 Between 2004 and 2005, formal economy employment grew by 250 000, while informal economy employment, if one ignores subsistence agriculture, grew by 500000 . 
"This is not to underplay the unemployment problem. According to the World Bank, at 56 percent, South Africa's labour force participation is low compared with 75 percent in middle-income countries. What is critical is that, in acknowledging the problem and understanding its true, rather than imagined, origins, we are able through the Accelerated and Shared Growth Initiative South Africa (AsgiSA) and other programmes to find sustainable solutions." (Sunday Independent, August 20 2006)

There are two major problems with this statement. One of them is the distinct lack of fit between the asserted 'understanding of the true origins of the unemployment problem' and the peculiarities disclosed in Tables 3, 4 and 5. If other aspects of AsgiSA are based on equally flimsy analysis, it would be as well not to pin too much hope on the chances of that particular initiative meeting its goals. South Africa's labour market statistics may not be ideal; misunderstanding them or misrepresenting the complex message they send out, ill becomes the body charged with the formulation of policy to deal with unemployment, one of the major causes of poverty.

The other problem arises because the South African government insists on maintaining the fiction that discouraged workseekers do not belong among the ranks of the economically active. When this is done, the country's participation rate appears to be low, when compared with other middle-income countries. This nonsense originates in the Presidency. The Ten Year Review (PCAS, 2003) produced by that office states that:

"Employment rate [sic. This should be Economic activity rate. $\mathrm{CM}$ ] reflects the proportion of the economically active population who consider themselves employed or looking for work (narrow definition). The measure thus excludes that proportion of people who are of economically active age but who have given up on seeking employment. This latter group is no longer considered economically active. " (PCAS, 2003, p.126)

Equally ominously, the official estimates of the 'official' rate of unemployment were themselves rejected by no less an authority than the President himself. In his weekly column in ANC Today (20-26 May 2005), he wrote the following: 
"Citing Stats SA figures prepared on [the official] basis, [the Department of Labour's Labour Market Review of September 2003] said that $4,400,000$ people were unemployed in March 2004. According to Stats SA, these were people who were actively looking for jobs or trying to create work for themselves. On this basis, Stats SA said our official (narrow definition) unemployment rate in March 2004 was 26.9\%."

Given the structure of our society and our labour market, this means that in March 2004 there were at least 4 million South Africans walking about in our villages, our towns and cities "actively looking for work". This is such a large number of people that nobody could possibly have missed the millions that would be in the streets and village paths "actively looking for work" in all likely places of employment.

It, therefore, seems quite unlikely that the Stats SA figure is correct, if indeed it used the standard international ILO definition to determine the unemployment rate. If this is the case, this means that it becomes very difficult to assess ourselves relative to other countries, which might use the ILO definition more strictly."41

While the President's attempt at gauging the severity of the unemployment problem by the method of casual empiricism (appearance vs. reality) is mildly entertaining, the stinging

41 The article, one of three that referred to the unemployment figures, appeared in ANC Today: Online voice of the African National Congress, Volume 5, No. 20, 20-26 May 2005.

Reuters picked up the President's message on the 21 May 2005, and put out an article under the heading "Mbeki raises questions on SA jobless statistics". Amongst other things, it quoted the following statements by the President:

"Unfortunately, it is difficult to get an accurate picture of the job situation in the country. This is not to question the fact that we have a high unemployment rate," Mbeki said.

He said it was hard to understand how South Africa could have a jobless rate of more than 26 per cent when Brazil's stood at 10,8 per cent in March 2005.

"The central matter at issue in this regard is that if in fact such a difference exists, we would then have to undertake actions to address unemployment, fundamentally different than any other country in the world," he said.

The article also reports an earlier rejection of the unemployment figures that goes like this: "Finance Minister Trevor Manuel said in his February budget for 2005 that if more than 40 percent of people were unemployed, there would be a revolution in the country." 
critique of Statistics South Africa's conduct of its surveys is not. ${ }^{42}$ To be accused of gross incompetence in the conducting of the Labour Force Surveys (LFSs) is no laughing matter. ${ }^{43}$ It would be idle to suggest that the LFSs are without problems - their inability, for example, to measure subsistence agricultural and informal economy employment with any credibility has long been recognised. The unemployment estimates themselves, and the manner in which the questionnaires have been designed to measure unemployment, have been subjected to scrutiny on a number of occasions in the past. Although the paper by Schlemmer and Levitz (1998), and the famous Standing et al (1995) critique of the figures, raised doubts, no-one has succeeded so far in showing that the figures are wrong. More recently, an (unpublished) IMF/World Bank sponsored review of the LFS suggested a number of improvements. Several of these, including a slimming down of the survey, have been introduced. To date, they have had no noticeable effects on unemployment rates.

It is not known what pressure, if any, was applied to Statistics South Africa to encourage them to publish only the official unemployment rate (the Act governing the production of official statistics is supposed to protect the Statistician-General against such influences). Whatever the case, the March 2004 LFS (SR P0210, 28 September 2004) was the last to contain a full treatment of the expanded unemployed. The LFSs now offer instead, selected information on the discouraged (as though they were a breed apart, instead of a sad group, many of whom switch to active searching status at the faintest whiff of a job).

In the old days, the two forms of unemployment were described as 'strict' and 'expanded' unemployment. Prior to 1996, the official unemployment rate was said (in the 1995 October Household Survey) to represent:

“... the actual number of persons as determined in accordance with the expanded definition of unemployment, expressed as a percentage of the relevant economically active population." (P0317, 27 November 1996, p.vii)

$42 \quad$ Shooting the messenger is not an unheard-of response to bad news. To a government whose policies to tackle unemployment have not been very richly rewarded, persistently high unemployment rates are an unwelcome sign of failure, ergo, their rates are wrong. Incidentally, Wikipedia says that the sentiment "No one loves the messenger who brings bad news" dates back at least to Sophocles' Antigone (441 BC).

43 A dismissal of the LFS results implies a dismissal as well of General Household Survey figures. The LFS and GHS results, from entirely independent samples, track each other quite remarkably. If the President is correct about the LFS results, then the only way in which this could come about is for the surveys to be conducted with equal degrees of incompetence. 
News of the change in 'official' definition was first given in a special edition of the OHS which presented results for the years 1994-1997 (SR P0317.10, 13 August 1998). ${ }^{44}$ This publication stated that:

"The CSS has revised its definition of the official unemployment rate in line with the definition of the International Labour Organisation (ILO) used by more than eighty percent of both developed and less-developed countries, and by South Africa's major trading partners (see Appendix A)." (p.4)

To qualify as 'officially unemployed' the individuals concerned (a) must not have worked within the seven days prior to the interview, (b) must want to work and be available to start work within a week of the interview, and (c) must have taken active steps to find work or start some form of self-employment within the four weeks prior to the interview (p.8). Appendix A showed that among the countries that did not use the work-seeking requirement in the 'official' measure, one could find highly-developed lands like Norway and Sweden, sprawling, poor democracies like India, and struggling sub-Saharan nations like Gabon and the Central African Republic.

Research conducted by the then CSS (Central Statistics Service)) showed that the main reasons for the cessation of job-seeking activity were:

- a loss of hope of finding work (33 per cent),

- a lack of jobs in the areas in which respondents live (25 per cent), and

- $\quad$ a lack of money for transport to look for work (18 per cent) (SR P0317.10, 13 August 1998, p.8)

$44 \quad$ The comparative study giving results for the years 1994-1997 (SR P0317.10, 13 August 1998) was published in time for the 1998 Presidential Job Summit. Because full 1996 Population Census results were not available at the time, it was weighted to the census post-enumeration survey. When the much-delayed 1996 October Household Survey was published (P0317, 30 August 1999), a definitive set of results, weighted to the 1996 Population Census, finally became available. See P0317, 30 August 1999, p.3. 
Statistics South Africa's anxiety to comply with international practice in the matter of publishing unemployment statistics, would have received a substantial fillip from government's enthusiasm for meeting with the requirements of the IMF's Special Data Dissemination Series (SDDS), "established in 1996 to guide countries seeking access to international capital markets" (http://dsbb.imf.org/Applications/web/sddshome/, 7 Dec 2006). This commitment trumps all other arguments. Statistics South Africa would thus have had no need to furnish any further justification for the change. ${ }^{45}$ No argument in favour of the 'official' rate is required other than the fact that it is 'official' and is used by many countries, including South Africa's major trading partners. Interestingly, though, there is explicit recognition that at least for domestic policy purposes, the expanded rate may be appropriate or relevant. So much is clear in the following statement:

\begin{abstract}
"The CSS has reported the expanded rate as well as the new official definition of the unemployment rate in this release, partly for comparability with previous reports; and partly because, as the ILO notes, an expanded definition may be appropriate "in situations where conventional means of seeking work are of limited relevance, where the labour market is unorganised or of limited scope, where labour absorption is at the time inadequate... There are various indications that these circumstances are applicable to some extent in South Africa." (SR P0317.10, 13 August 1998, p.8)
\end{abstract}

A commitment to furnish 'official' rates of unemployment for the SDDS has no bearing on whether or not the expanded unemployment results are published as well. ${ }^{46}$ Excluding them from the ranks of the unemployed smacks of political expediency - four million sounds less bad than eight million. As Kingdon and Knight (2000) demonstrated several years ago, differences between the searching and the non-searching unemployed (the official and expanded unemployed) that would justify their being treated differently for policy purposes, do not exist. If, however, government decrees that the discouraged are not to be counted among the economically active, then it follows that South Africa's

\footnotetext{
$45 \quad$ They could, under other circumstances, have searched for evidence that investment decisions are sensitive to unemployment rates, thus rendering internationally comparable results necessary.

46 The fact that the ILO recommends using only the 'official' rate of unemployment is irrelevant - as we have seen above (Footnote 3), the bulk of the discouraged do not search for work because they do not believe (and reasonably so) that there is any to be had.
} 
participation rate will be lower than it would have been if all of the unemployed were taken into account. The World Bank conclusion, cited by Netshitenzhe above, that the participation rate than that in comparable middle income countries, is thus the beginning, not the end of an analysis. That analysis should aim at discovering the relative proportions of the discouraged, and of the potential among the economically inactive for changing their status to economically active, in the countries the Bank asserts to be comparable with South Africa. Until such an analysis is performed, international comparisons of the type referred to by Netshitenzhe are meaningless. ${ }^{47}$

47 At 67-68 per cent, South Africa's participation rate is not all that far from those of other middle-income countries. There is not much slack left in the labour market - most of the economically inactive have plausible reasons for being so, the most important of these being the fact that many are still at school. Servaas van der Berg made this point in his presentation at the DPRU Conference in October 2006. It is not in the paper circulated for the conference. 


\section{Progress in the Struggle Against Poverty?}

Poverty is a political problem. The land is bountiful - there is more than enough for everyone to live well above poverty levels. The fact that some starve while others die of diseases of over-consumption is the outcome of political choices, past and present. Solving the poverty problem is possible only if appropriate policy choices are made. Making and implementing those choices requires reliable information, a commodity seemingly in short supply.

When poverty is as widespread as it is in South Africa, the time and energy devoted to formulating and implementing policies to reduce, or better still, eradicate poverty must needs be large. If commitment to these goals were gauged by the number of measures introduced (and the amount of money thrown at the problem), government's performance would be rated highly. How effective these measures have been, is, however, a different matter.

For many years, poverty researchers have claimed that both poverty and inequality have worsened. Rather obviously, such claims will be, and have been poorly received by politicians. Government has responded by repeatedly pointing to the vast amounts spent each year on the 'social wage' (essentially, housing, health, sanitation, education, electricity, and water, plus social grants). This has not, as we have seen above, stilled the protests about poverty (and poor service delivery).

Then, at the end of September 2005, like manna, came the news from Professor Servaas van der Berg and his colleagues in the University of Stellenbosch, that the poverty headcount (the number of people below the poverty line), having climbed from about 16.2 million in 1993 to 18.5 million in 2000, fell thereafter to 15.4 million in 2004 . The poverty line used was R250 per capita per month in 2000 prices (van der Berg et al, 2005, p.17), which amounted to about R10 per day per person in 2004. The primary cause of the drop in the poverty headcount (and the improvement in the conditions of those still below the poverty line) is said to be the massive increase in the numbers of people receiving social grants. 
Government lost a little, but not much time, ${ }^{48}$ before harvesting the propaganda fruits of these findings. President Mbeki used the van der Berg et al figures to reassure Prince $\mathrm{N}$ E Zulu, during question time in Parliament on March $30^{\text {th }}$ 2006, that government was on course to halve the poverty rate by 2015 . The numbers surface again in A Nation in the Making: A Discussion Document on Macro-Social Trends in South Africa (PCAS, 2006, p.12), the follow-up to the Ten Year Review (PCAS, 2003). ${ }^{49}$ Netshitenzhe uses them once more in his critique of Pilger (Sunday Independent, August 20 2006), in an attempt to show that the conditions of the poor are not as bad as Pilger claims. Given that one of Pilger's favourite quotations is some advice from Claud Cockburn, who said "Never believe anything until it is officially denied", denial will presumably have confirmed (for him) that he is on target, even if not in the bulls-eye. And he [Pilger] would be right to be suspicious, for despite Netshitenzhe's (and the President's) apparent confidence in the van der Berg et al results, they certainly do not deserve the appellation 'facts' - they are, as suggested above, one among a set of competing artefacts produced by a group of social scientists.

\section{a. Different Database - Different Artefacts}

Professor van der Berg and his co-workers have created one set of artefacts - here is an alternative set - using the same poverty line as they did, research I have undertaken suggests that the poverty headcount in 2004 was about 18 million, and about 19.5 million in 2001 (Meth, 2006a; 2006b). Instead of a fall in the headcount of three-million reported by van der Berg et al, my guess is thus that it was closer to one-and-a-half million. A brief description of the way I arrive at my estimates follows.

The 18 million people below the poverty line can be divided into two groups. About 14 million of them were in 'workerless' households, most of which contain working age people, none of whom reports having done any work, paid or unpaid, ${ }^{50}$ in the seven days

$48 \quad$ There was no mention of their results in the President's State of the Nation speech (3 February 2006). The President refers instead to the social wage paper by Bhorat et al (2006). In the Minister of Finance's Budget Speech (15 February 2006), poverty and the social wage are each mentioned once by name. Poverty statistics are not discussed. The social wage is treated at some length. Apropos the education component of social spending, the Minister, with characteristic flair, said that "School fees will be phased out in low-income communities this year, and Minister Pandor confirms that in three weeks time the last remaining 17 trees will no longer substitute for classrooms." If true, this is good news.

50 The unpaid labour of 'homemakers' (chiefly housewives) does not count as work for purposes of the employment definition. Several other unpaid activities do - of the eight listed, only begging does not count as employment. Any of the other seven activities need only have been performed for one hour during the reference period to qualify as employment. See Question 2.1 in 
prior to the LFS interview taking place. People in these households survived on a mix of social grants and/or migrant remittances. Among the remaining four million people (located in 700000 households) about 800000 were employed. Their presence below the poverty line indicates that the problem of the working poor is still very much with us. Research into ways of dealing with it is urgently required.

On the positive side, the poverty rate (the proportion of people below the poverty line) even if it did not fall by the amount suggested by van der Berg et al, is likely to have fallen. In the absence of such a fall, and the improved social protection by which it was caused, poverty would have been much worse. The poverty gap (the sum that would need to be transferred to the poor each year to raise all of them above the poverty line) has probably fallen as well. It has done so in both absolute terms (the size of the transfer) and in relative terms (the proportion it represents of GDP).

Since full descriptions are available in two recent papers (Meth, 2006a; 2006b) of the means by which my results have been extracted from their primary data sources, ${ }^{51}$ only the briefest of descriptions of their origins, and of the way in which the numerous obstacles encountered en route were addressed, need be offered here. Once that has been done, we take a look at the plausibility of the claim that three million people were lifted over the poverty line between 2000 and 2004, mainly by social grants. The paper concludes with a few recommendations, one of which refers to the need, given the highly politicised nature of the debate over poverty and inequality, for greater care in the production and use of estimates that purport to measure their severity.

\section{b. Matters Methodological}

Understanding poverty in South Africa, at least on a national scale, a difficult enough task as it is, is made more difficult still by inadequacies in the survey and census data on which research must be based. Among the limitations are (i) the fact that survey respondents under-state income and expenditure levels, (ii) surveys miss some forms of income, e.g., investment income such as rent, interest and profit, and (iii) there are

the September 2004 LFS. Information on time spent fetching water and wood or dung (Questions 1.14-1.17) is collected, but this is not treated as employment. Satellite accounts for activities such as domestic production, that take place outside of production boundary of the System of National Accounts (SNA) and that are consistent with the SNA, can be constructed. Few countries, however, do so.

51 The Labour Force Surveys for September 2001 and September 2004, and the General Household Survey for 2004. 
many households for which income is unknown (the income estimate is returned as zero) because respondents refuse to answer income questions, or do not know the answers to the question. These problems are faced, in varying degree, by all poverty researchers.

Because income and expenditure is under-reported in surveys, the value of total income or expenditure that can be estimated from household surveys is invariably smaller than the total estimated from the national accounts. Reliance on unadjusted survey figures is likely to cause poverty to be over-stated. One technique for dealing with this problem is to raise survey totals (or means) to match national accounts totals (or means). National accounts, however, are argued to overstate absolute income levels. Using them to adjust survey incomes for under-reporting, could, depending on the way in which adjustments to income are distributed, cause poverty to be under-stated. Their use for this purpose is therefore not recommended (Ravallion, 2000, 2003: Deaton, 2003).

Part of the source of the van der Berg et al results is a hitherto untouched (as far as poverty studies are concerned) set of surveys, the All Media and Products Surveys, (AMPS). This innovative attempt to break out of the straitjacket of reliance on official statistics is thoroughly commendable. To deal with the under-reporting problem, however, they flout Deaton's and Ravallion's recommendations, saying that they:

“... trust national accounts data for aggregate household income, [and] trust survey data for the distribution of such income between households." (van der Berg et al, 2005, p.11)

Doing so must at least raise questions about the methodological soundness of their approach, and hence, of the reliability of their findings.

In their paper, van der Berg et al engage critically with existing poverty studies in South Africa. Most of these are based either on the population censuses of 1996 and 2001, or the marriage of the Income and Expenditure Survey (IES) of 1995 to the 1995 October Household Survey (OHS), and the similar pairing of the 2000 IES with the LFS of September 2000. Not only are these data sources more than somewhat dated, they have been mined so extensively that they are probably approaching the point of exhaustion. If any further insights are to be gained from existing official statistics, they are going to have to come from the two major household surveys, the Labour Force Survey (LFS) and the 
General Household Survey (GHS). ${ }^{52}$ Far from being fully-exploited, the Labour Force Surveys (at least up until September 2004) and the General Household Surveys offer a wealth of data from which plausible estimates of the extent of poverty can be squeezed.

Although neither the LFS nor the GHS are designed to measure poverty, ${ }^{53}$ one advantage they have over the AMPS when pressed into this duty, is that they collect information on both income and expenditure. The AMPS, by contrast, whose purpose is also not to answer questions about poverty, only collect information on income, and then only in intervals or categories. ${ }^{54}$ Because the LFS and GHS collect both expenditure and income data, it is possible to impute expenditure estimates where income figures are missing, and vice-versa. The independence of the income and expenditure data also allows estimates of poverty made from one source to be checked against the other. Accordingly, I made one set of estimates using the expenditure data (Meth, 2006a). This was followed by a paper containing a second set of estimates (Meth, 2006b), extracted from the income data in the surveys. It is from the latter paper that the results given in this section of the present paper are taken. They offer support to the findings of the earlier paper. Obstacles encountered along the way fell into four categories. Three of them plague almost all censuses and surveys. They are: missing income estimates; implausible the zero-income estimates and under-reporting of income and expenditure. The fourth, the inadequacy of the data on social grants collected by the Labour Force Surveys (LFSs), is peculiar to that survey.

Among the employed in September 2004, only 6.8 per cent of respondents did not furnish adequate income data. ${ }^{55}$ After imputation based on household expenditure data, the proportion of the employed for which no income data was available, was reduced to 1.8 per cent. The bulk of these were among (mainly white) households which refused to supply both income and expenditure data. They are assumed to be unlikely to be poor.

$52 \quad$ Earlier Income and Expenditure Survey (IES) used the recall method to capture data. The current survey uses the diary method. It is not possible to tell yet, what insights may come from the revamped IESs.

53 Both surveys have their origins in the October Household Survey, last conducted in 1999. That the OHS was intended to be used as an instrument for monitoring poverty is made clear in the explanatory notes. See SR P0317, 31 July 2000, p.i.

54 It has been suggested that there are problems with the AMPS sampling. I have not made any attempt to delve into that question. Although I offer a few critical observations on the approach adopted by van der Berg et al (2005), the aim of the two papers I wrote (Meth 2006a and 2006b) was not to develop an extensive critique of their work. Rather, it was to show that plausible estimates of poverty could be extracted from household surveys conducted by Statistics South Africa. Given the sample sizes of the AMPS and the Stats SA surveys, one would expect them to generate similar results. The fact that they do not, creates a research agenda. Sooner or later, the question of why they do not, will have to be addressed. 
Workerless households, by definition, do not receive any of their incomes in the form of earnings from persons in the household. At the bottom (the poor end) of the income distribution, these zero-(earned) income households subsist on social grants and migrant remittances. After allowing for income from these sources in the roughly four million workerless households that contained more than 14 million people below the poverty line in 2004, the number of people for whom no incomes could be found dwindled to about 1.8 million. A possible explanation for their lack of income is the shortness of the reference period during which reported incomes were received (the seven days previous to the interview). The people involved have the typical characteristics of the poor. It is argued that zero-incomes (earned in the reference period) among this group are not implausible.

Under-reporting of income and expenditure is considered at some length in Meth (2006a and 2006b). In the latter, the paper from which the results considered here are taken, the adjustment required to raise estimated survey total income to national accounts totals, is in the region of about 80 per cent, i.e., earned income is multiplied by $1.8 .^{56}$ There is, of course, no guarantee that the national accounts figures are correct - the burden of the Deaton article cited above (2003), for example, is precisely that they are not, national accounts being argued to overstate incomes. The point of raising incomes to national accounts levels is to see what sort of poverty estimates results when the Statistics South Africa household surveys, rather than the AMPS are used to generate the relevant distributions.

In any event, arriving at the figure of 80 per cent entails making the assumptions that (a) under-reporting of earned-incomes is uniform across all income groups, and (b) that investment income that is not detected by the LFS amounts to about 15 per cent of the national accounts income estimate. Evidence in support of these assumptions is difficult to obtain. There is a suggestion in the literature that under-reporting is a monotonically increasing function of income. Arguments could be mustered to suggest that the underreporting function may be U-shaped, being most significant at very-low and very-high incomes. In the absence of convincing evidence in support of this, the uniform assumption is preferred. In any case, there are so few workers among poor households, that to get somewhere near the van der Berg et al results, it has to be assumed that earned incomes are under-reported by 200 per cent or more (i.e., actual earned income is three times as high as reported income). Roughly similar income patterns to those yielded by the

$56 \quad$ The adjustment to correct for a 100 per cent under-reporting error is a doubling of earned incomes. 
September 2004 LFS are reported by the 2004 GHS. It seems unlikely that respondents in two completely independent surveys would tell similar lies about incomes. Unless convincing evidence of bias among low-income respondents can be found, modesty dictates that an adjustment in the region of about 80-85 per cent would be appropriate. This, as noted above, would raise total survey income to roughly the same as the national accounts total. If the South African national accounts are prey to over-estimation of income and expenditure levels as Ravallion (2000, 2003) and Deaton (2003) suggest is the case elsewhere in the world, then an assumed under-reporting error of that level ${ }^{57}$ would probably be conservative in that it would tend to understate poverty.

Prior to September 2004, both the GHS and the LFS set out to capture information on the receipt of social grants. ${ }^{58}$ Of the two, the GHS did a better (though not quite satisfactory) job. This was because of the wording of the relevant questions. The LFS merely asked whether anyone in the household received any of the listed grants, whereas the GHS asked which individuals received them. Comparing both surveys with the administrative data from the Department of Social Development (the SocPen database) discloses their inadequacies in the collection of data on the 'big three', the old age pension, disability grants and the child support grant. Of about 3.05 million people lifted over the poverty line of R309 per month per capita in 2004 (R250 in 2000 prices), the big three (in terms of numbers of beneficiaries) are responsible for about 3.02 million. Doubling or even trebling numbers of the lesser grants (foster care, care dependency and the grant-inaid) would have a measurable, but small effect on numbers in poverty. Attention was focused, therefore, on the big three when it came to devising ways to compensate for the weakness of the LFSs in their role as collector of information on social grants. The GHS finds too many state old age pensioners. Correcting the LFS by multiplying the number of households reporting receipt of a pension by the mean number of pensioners per household reported by the GHS brings the LFS totals close to the administrative data. Not much more was necessary as far as the pensions were concerned. Child support grant numbers were taken over the top of the administrative figures by awarding a grant to a household reporting receipt of the grant and containing one eligible child; two to a household containing two eligible children, and so on, where eligibility was determined by age alone (less than 12 years, the age group reached by the grant system in 2004). To deal with the over-estimate of the number of grants paid out, their value was scaled

57 The $80-85$ per cent under-reporting error is coupled with the estimate that the surveys miss an assumed 15 per cent of total national accounts income in the form of investment income. The LFS no longer collects information on grants, or on household expenditure, a serious loss - see Meth 2006a and 2006b. 
downwards to make total payout the same for the survey as it was according to the administrative figures.

Most troublesome to deal with adequately was the disability grant. Although it may be appropriate to argue that almost all of the disability grant payout goes towards the reduction of the poverty gap, it is not correct to treat the grant's impact on the poverty headcount in a similar way. This is because the extent to which the grant is capable of meeting the special needs of the disabled is not easily determined. In their profile of social security beneficiaries in South Africa, de Koker et al (2006) give an indication of the extent of 'additional expenses incurred due to disability' (Section 5.3.5.2). Some of the sums involved are substantial. Information on four categories of expenditure, medical, extra assistance or care, regular therapy or treatment and other expenses is presented in Tables 5.76-5.79 (Vol. 1, pp.225-228). In other words, the poverty line for the disabled is likely to be quite a lot higher than that for the non-disabled. From the profiles in Vol. 3 of the work, it would appear that most of the households receiving disability grants are very poor. Only four per cent of beneficiaries were employed, while 21 per cent of the households in which they live report having missed a meal in the previous month for want of money (Vol. 3, pp.653-654). On these grounds, it seems reasonable to assume that consumption levels of the members of some (unknown) proportion of the poor households into which disability grants flowed would still have fallen below the poverty.

Partial compensation for the fact that the LFS undercounts the number of disability grants is made by multiplying the value of the grant going into households by the ratio of the number of grants detected by the GHS, to the number of households reported by the LFS as receiving at least one disability grant. This pumps up the value of the grant going into mainly poor households, making some (arbitrary) correction for the condition referred to above, namely the fact that a poverty line of R250 per month per capita almost certainly does not allow for the special needs of many of the disabled to be met. A more parsimonious correction assumes that only half of the 1.36 million grant recipients recorded by the administrative data receive enough to meet their needs. The value of the grant is scaled downwards and delivered to the 894000 households detected by the LFS. These two assumptions are called respectively (the first of them somewhat misleadingly), the full value and half value assumptions.

Migrant remittances presented the final problem that had to be dealt with to produce a set of poverty estimates. The question here is with the extent of under-reporting of remittances. Two assumptions are used - one that under-reporting is zero; the other that 
under-reporting of remittances is the same as that of other earned incomes. Together, the procedures described above yield Table 6 (Table 6 in Meth, 2006b).

Table 6: Poverty Estimates, 2004 - Income from all Sources

\begin{tabular}{|c|c|c|c|c|}
\hline Error level & Zero & $75 \%$ & $100 \%$ & $200 \%$ \\
\hline \multicolumn{5}{|c|}{ 1. Half-value disability grant, Zero under-reporting of remittances } \\
\hline Headcount ratio $\left(P_{0}\right)$ & 0.507 & 0.423 & 0.395 & 0.365 \\
\hline Poverty gap ratio $\left(P_{1}\right)$ & 0.286 & 0.245 & 0.237 & 0.216 \\
\hline Headcount & 23200000 & 19300000 & 18400000 & 16700000 \\
\hline Poverty gap Rbn & 45.5 & 38.5 & 37.1 & 33.4 \\
\hline \multicolumn{5}{|c|}{ 2. Half-value disability grant, Remittance under-reporting same as income } \\
\hline Headcount ratio $\left(P_{0}\right)$ & - & 0.408 & 0.376 & 0.358 \\
\hline Poverty gap ratio $\left(\mathrm{P}_{1}\right)$ & - & 0.235 & 0.224 & 0.209 \\
\hline Headcount & - & 18600000 & 17600000 & 16400000 \\
\hline Poverty gap Rbn & - & 36.7 & 34.9 & 32.2 \\
\hline
\end{tabular}

3. Full-value disability grant, Zero under-reporting of remittances

\begin{tabular}{rrrrrr|r} 
Headcount ratio $\left(\mathrm{P}_{0}\right)$ & 0.495 & 0.413 & 0.386 & 0.332 \\
Poverty gap ratio $\left(\mathrm{P}_{1}\right)$ & 0.277 & 0.237 & 0.229 & 0.197 \\
Headcount & 22600000 & 18900000 & 18000000 & 15200000 \\
Poverty gap $\mathrm{Rbn}$ & 44.0 & 37.0 & 35.7 & 30.1
\end{tabular}

4. Full-value disability grant, Remittance under-reporting same as income

$\begin{array}{rrrrr}\text { Headcount ratio }\left(P_{0}\right) & - & 0.399 & 0.367 & 0.325 \\ \text { Poverty gap ratio }\left(P_{1}\right) & - & 0.227 & 0.216 & 0.191 \\ \text { Headcount } & - & 18200000 & 17100000 & 14900000 \\ \text { Poverty gap Rbn } & - & 35.3 & 33.4 & 29.0\end{array}$

Source: Own calculations using September 2004 LFS data set

Note: All sources means all income from employment, migrant remittances and all social grants

Poverty in September 2004 is probably going to be somewhere in the region shaded grey in the middle of the table (as noted above, making a 100 per cent income under-reporting adjustment would be excessive). In place of the van der Berg et al (2005, Table 2) poverty headcount ratio of 0.332 , we are looking at something in the region of 0.39 , while the poverty gap ratio, instead of sinking to 0.146 in 2004 from 0.205 in 2000, as they suggest, was possibly about 0.23 . Translating the latter into the value of the annual transfer that 
would need to be made to eradicate poverty (as defined by the miserly R250 line!) would be about R35 billion per annum (in 2004 prices). This was less than four per cent of the value of the national accounts estimate of income in 2004.

As may be seen, the headcount hovers somewhere around the 18-million mark, depending on what assumptions are deployed. The estimates are sensitive to the assumptions, but even on the most parsimonious of them (with survey total income almost certainly climbing above the national accounts total) the headcount does not fall below 17 million. So much for the 2004 estimate - let us look now at the figures for 2001.

\section{c. Changes in Poverty 2001-2004}

An estimate of changes in poverty levels between 2001 and 2004 is presented in Table 7. ${ }^{59}$ The September 2000 LFS cannot be used to test the proposition (from the van der Berg et al piece) that the headcount fell by three million or so between 2000 and 2004, because in its infancy, the LFS did not ask for expenditure data. ${ }^{60}$ The non-response problem for the income questions in the September 2000 LFS cannot be addressed with any ease because the absence of expenditure data robs us of the simple method by which to impute incomes.

Fortunately, the expenditure question (which used to be in the October Household Surveys - OHSs) was restored to the LFSs in September 2001. Non-responses or poor responses to the income question do not disappear in that and subsequent LFSs (and GHSs as well). The expenditure questions in them, however, elicit far fewer 'Refuses' or 'Don't knows' (or other forms of missing information) than do the income questions. That makes it possible to impute income for all but a small percentage of the workforce, even if the simple category-type questions only permit rough approximations. ${ }^{61}$ So, although it is not possible (or, at least, not very easy) to look at changes in poverty over the period 2000-2004, it is possible to do so for the period 2001-2004.

\footnotetext{
$59 \quad$ This is Table 8 in Meth (2006b).

60 The first LFS was conducted in February 2000, the last October Household Survey having been carried out in 1999.

61 Where expenditure fails us, it has at least been possible to use race as a proxy (albeit a very crude one) to permit an educated guess to be made of the likelihood of particular workers being poor.
} 
Three sets of results are presented, two of them for the year 2004. One set is obtained from the September 2004 LFS and the other from the GHS for that year. Neither the GHS nor the September 2001 LFS collected data on migrant remittances. To make the September 2004 LFS figures comparable, it is necessary, therefore, to strip remittances from the income definition. It is also necessary to treat disability grants for the two years in the same way. Accordingly, the September 2004 LFS figures in Table 7 use the 'full value' assumption (described above) for disability grants. Poverty headcounts for September 2004 thus exceed their counterparts in Table 6 by the amount by which remittances reduce poverty. A little mental arithmetic suggests that remittances appear to lift somewhere between one and one-and-a-half million people over the poverty line (depending on the extent to which incomes and remittances are under-reported). Lest it be thought that this number is small, it should be borne in mind that remittances fulfil the vital function of sending income into workerless households, even if they are not large enough to lift many of these households out of poverty. 
Table 7: Poverty in South Africa, 2001-2004

\section{GHS}

Error level

Headcount ratio $\left(P_{0}\right)$

Zero

Poverty gap ratio $\left(\mathrm{P}_{1}\right)$

0.542

0.231

0.186

$75 \%$

$100 \%$

$200 \%$

Headcount

25100000

21300000

0.442

0.401

Poverty gap Rbn

55.0

47.5

0.180

0.155

20400000

18600000

46.3

42.0

\section{September 2004 LFS}

Error level

$\begin{array}{rr}\text { Headcount ratio }\left(\mathrm{P}_{0}\right) & 0.510 \\ \text { Poverty gap ratio }\left(\mathrm{P}_{1}\right) & 0.305\end{array}$

Zero

$75 \%$

$100 \%$

$200 \%$

Poverty gap ratio $\left(\mathrm{P}_{1}\right)$

23300000

0.427

0.399

0.370

Headcount

0.262

0.255

0.235

Poverty gap Rbn

48.8

19500000

18600000

16900000

41.4

40.1

36.6

\section{September 2001 LFS}

Error level

Zero

$75 \%$

$100 \%$

$200 \%$

Headcount ratio $\left(P_{0}\right)$

0.549

0.459

0.439

0.389

Poverty gap ratio $\left(P_{1}\right)$

0.375

0.322

0.310

0.310

Headcount

24800000

20700000

19800000

17600000

Poverty gap Rbn

50.5

43.0

41.3

37.7

Change: Sept 01-Sept 04

$-1500000$

$-1200000$

$-1200000$

$-700000$

Source: Own calculations using September 2004 LFS, the 2004 GHS, and the September 2001 data sets . Revised weights, supplied by Statistics South Africa, have been applied to the 2001 LFS data.

Note: Income equals income from employment plus social grants. No data on remittances are collected by the GHS and the September 2001 LFS.

There are three striking features in the results in Table 7. The first is that it looks, from the two sets of LFS results, as though the headcount fell by about 1.2 million over the three years, a far cry from the 3.1 million reported by van der Berg et al for the four-year period. The second, however, is the quite substantial drop in the poverty gap ratio (possibly from about 0.316 to about 0.258 ). Third are the big differences between the LFS and GHS results for 2004 , the latter generating a far more gloomy picture. 
Digging into the finding that the poverty headcount fall between 2001 and 2004 could have been about 1.2 million (let us be generous and say that it could have been as high as 1.5 million) if we discount the zero-error and 200 per cent error estimates, it could be argued that this is not inconsistent with expectations. A substantial part of the social grant system was already in place, ${ }^{62}$ employment growth was slack, and there were simply not enough workers in poor households for income growth to have made much of a dent in poverty.

To reject the finding that the fall in the headcount was approximately one-and-a-half million (instead of three million), a number of arguments could be advanced, the first being that it is inappropriate to use two sets of cross-section survey results as though they were time-series data. If this objection is valid, however, it must apply with equal force to the van der Berg et al effort, which does the same thing with AMPS survey data. Another possible problem is that the sample for the 2001 LFS was not adequate. ${ }^{63}$ It is also possible that the survey design is such that unemployment, the major cause of poverty in South Africa, is significantly overstated, while employment is understated. To investigate fully each of the ways in which the results may have been infected, is no small undertaking. As a researcher, I am compelled, as are van der Berg et al (2005, p.), ${ }^{64}$ to take certain findings on trust. The onus is upon those who would dismiss my findings, to show why it is inappropriate for me to have relied upon the sources in question.

Although estimated declines in headcounts in Table 7 are relatively slight, the falls in the headcount ratio are fairly substantial. Possible increases in poverty caused by population growth, on the one hand, and the reduction in poverty caused by the extension of the social grants, ${ }^{65}$ on the other, are working in opposite directions, with the latter dominant, in

$62 \quad$ See Table 4 in Meth (2006b).

63 The 'missings', 'don't knows' and 'refuses' among respondents in the September 2001 LFS are similar in proportion and number to those in the September 2004 LFS. In 2001, there were 26532 employed respondents. Of them, 18920 (71.3 per cent) gave point estimates of income, while 5997 (22.6 per cent) gave category estimates. 'Missings', 'don't knows' and 'refuses' numbered 1618 (6.1 per cent of the employed). After imputation using data on expenditure, this was reduced to 637 cases (2.4 per cent of the employed). Source: own calculations using September 2001 LFS data set.

64 They "trust national accounts data for aggregate household income" and AMPS "survey data for the distribution of such income between households." (2005, p.11)

65 In the absence of the increases in the numbers of social grants, poverty would obviously have been much worse in 2004. Applying the 2001 headcount ratios to the 2004 population suggests that there would have been somewhere between 1.8-2.2 million more poor people in 2004 than are reported in Table 7. 
part, because population growth rates are falling. ${ }^{66}$ This outcome prompts a consideration of the contribution, positive or negative, of population growth to poverty reduction. South Africa's poverty reduction goal, like that of the other countries committed to the achievement of the Millennium Development Goals, is one of halving the 'rate', i.e., the headcount ratio $\left(P_{0}\right) \cdot{ }^{67}$ The adoption of such a goal does not mean that headcount itself must fall as well - it is quite possible for population growth to cause headcounts to rise while headcount ratios fall. Whether, under such conditions, one can say that poverty had 'gone down' is one of the 'hard questions' posed by Kanbur (2004, pp.6-7). As we shall see below, however, population growth rates in South Africa have fallen so much, that there is now little chance of such a question having to be answered.

Poverty in the period 2001-2004 in South Africa appears, however, unambiguously to have 'gone down'. The headcount ratio $\left(P_{0}\right)$ and the headcount, as well as the poverty gap ratio $\left(P_{1}\right)$ and the poverty all fall. The critical question, of course, is, by how much? Presumably emboldened by the van der Berg et al (2005) findings on poverty reduction, senior politicians, as we have seen above, have taken recently to asserting with confidence that the poverty halving goal will be met. ${ }^{68}$ It is not known if these assertions are based on a model, or are merely back-of-envelope calculations informed by the apparent success of poverty reduction in the period 2000-2004.

Building a model to speculate on future possibilities is, of course, simplicity itself (how accurate its predictions are, depends entirely, of course, on how well the future values of the relevant variables have been guesstimated). Assume that, because full take-up of the planned extensions to South Africa's social grant will soon be reached, the van der Berg et al poverty reduction estimates for period cannot be extrapolated very far into the future.

$66 \quad$ Population growth rates for the years 2001-2002; 2002-2003; 2003-2004; 2004-2005 and 2005-2006 respectively are, 1.25; 1.22; 1.19; 1.17 and 1.06. See mid-year population estimates for 2006 (P0302, 1 August 2006, Table 5, p.6). The decline in the population growth rate after 2004 (0.11 percentage points) is much larger than those in previous years. Population growth rates in the 2006 release are higher than the corresponding rates in the mid-year population estimates for 2005 (P0302, 31 May 2005, Table 7, p.10).

67 In South Africa's case, the target year is 2014 , the $20^{\text {th }}$ anniversary of the commencement of democratic rule, rather than by 2015. It is not obvious what base year the South African government has in mind. The United Nations uses 1995. Because of the fragmented nature of South African statistics, poverty levels in 1994 or 1995 are the subject of some disagreement. AsgiSA seems to suggest that the intention is to halve the rate of poverty to "less than one sixth of households". This precedes a statement which says that "there remain about a third of South African households not yet able to benefit directly from our economic advances". I take it that this is a way of saying that the (household) poverty rate is (currently) about 0.33 . One could conclude from this that the base year is 2006 .

68 Recall that President Mbeki used the figures to reassure Prince N E Zulu, during question time in Parliament on March 30'2006, that government was on course to halve the poverty rate by 2015 , while Joel Netshitenzhe uses them to make the same claim in his critique of Pilger (Sunday Independent, August 20 2006). 
Assume, instead, that the headcount falls by three million between 2004 and 2014. With a sustained decline in the population growth rate of 0.06 percentage points each year from a reported population growth rate of 1.17 per cent per annum in 2004-2005, the headcount ratio would fall from 0.410 to 0.314 . Using these same assumptions, but aiming for a halving of the poverty headcount ratio (to 0.205 ) in 2014 , would require the headcount to fall from 18.6 million in 2004 to 10.2 million in the end year, a tall order. ${ }^{69}$ Interestingly, the poverty halving goal becomes harder to achieve (in absolute terms) as the fall in the population growth rate accelerates. This is because a smaller end-year population with a given headcount ratio, yields a smaller headcount in the end-year, thus raising the number that have to be lifted out of poverty between the start-year and the end-year.

Unless the rate of poverty reduction, as measured by the headcount ratio, slows to a barely discernible trickle, it is highly unlikely, in South Africa's case, that Kanbur's hard question of whether a fall in the poverty rate accompanied by a rise in the poverty headcount, constitutes a reduction in the severity of poverty, will be posed. HIVIAIDS has reduced the population growth rate by enough to ensure that even a slight fall in the headcount ratio will be accompanied by a fall in the headcount itself. It would be sobering, amidst the premature celebration of the likely attainment of the poverty halving goal, for the contribution of this awful epidemic to that (possible, but unlikely) achievement, to be acknowledged.

\section{d. A Three-Million Headcount Fall, 2000-2004?}

Poverty reduction can come about for three reasons: employment growth; earnings growth and increases in social grant income. The claim by van der Berg et al that the number of people living in poverty fell by three million between 2000 and 2004 does not receive much support from the available evidence. That evidence is reviewed in Meth (2006b). It is not the intention to do much more than to summarise the major findings here.

69 To produce a situation in which the hard question about poverty arises to which Kanbur (2004) refers, it would be necessary to have population growth rates not seen in South Africa for a long time, as the following (obviously hypothetical) example shows. All other things being equal, if we start with a headcount ratio of 0.41 in 2004 , and we assume that the population growth falls by 0.02 percentage points per annum, the headcount would remain static over the period 2004-2014, if the population growth rate in 2004 had been 2.5 per cent per annum. The headcount ratio in 2014 would then be about 0.325 . If the population growth rate did not fall, the headcount would begin to rise slowly, thus prompting the Kanbur 'hard question'. 
As far as employment is concerned, it looks as though those in the best-off households scored handsomely, while the numbers employed at lower income levels fell. The number of workers living in households with incomes of R10 000 or more per month, increased by more than 600000 between 2001 and 2004. In households where income was less than R1236 per month, home to more than 70 per cent of the poor, over 200000 jobs were lost between 2001 and 2004. In the van der Berg et al paper, a simulation exercise (2005, p.21) finds a pro-poor bias to one million hypothetical jobs. If the LFSs are to be believed, the reality is quite the opposite.

For evidence of earnings growth, we turn to the work of two of the co-authors of the van der Berg et al (2005) paper, Burger and Yu (2006). The authors present their results in graphical rather than table form. This is a bit of drawback, because one has to guess at the numbers underlying the graphs. It is also a bit of a blessing, however, because it makes it clear, at a glance, that interpretation is sensitive to end-point selection. Looking at their Figure 3 (p.8), if one starts with the very first LFS, earnings of informal economy workers appear to increase from about R500 per month (in 2000 prices) in February 2000 to about R900 in September 2005. Real earnings in September 2000, however, look as though they were about R800 per month. They dip (inexplicably?) to about R600 per month in February 2001, only to climb again. This erratic behaviour undermines the validity out of their claim that "the earnings of the self-employed have been steadily increasing" (2006, p.8). Real earnings of the self-employed show a more substantial increase, possibly from about R1900 to about R2500 between September 2000 and September 2004 (2006, Figure 4, p.9). These folk, however, are unlikely to have been numbered among the poor in the first place, so are not of great interest to us. A similar conclusion holds for workers in the formal sector, where average earnings rise from about R2700 to R2800 per month between September 2000 and September 2004 (2006, Figure 5, p.10). African workers in the formal sector see their average real earnings rise from about R1800 to R2000 per month between September 2000 and September 2004 (2006, Figure 8, p.12). Average earnings of the unskilled show precious little change over the period September 2000 and September 2004 (2006, Figure 10, p.13), possibly rising from about R900 in 2000 to R1000 in 2004.

There is little in all of this to encourage the belief that rising real incomes contributed much to the decline in the poverty headcount asserted by van der Berg et al to have taken place between 2000 and 2004. If employment of lower skilled workers fell, or was static, as the figures in Table 11 in Meth (2006b) suggest (and as one would expect in a time of high and rising unemployment), there would be even less reason to believe that any part 
of the asserted headcount fall was due to income increases. In short, the case for poverty reduction of the magnitude they claim comes to rest on social grants.

\section{e. Social Grants}

Without social grants, it is safe to say, conditions among the poor would have been dire indeed. The grants appear to have lifted about 1.7 million people over the poverty line in 2001 (and brought many others below it, closer to the line). By 2004, rapid expansion in the number of grants made, raised the number released from poverty to about 3.2 million. So, although there was a large increase in the number of social grants, the increase was not enough to lift more than an additional 1.3 million-1.5 million or so people out of poverty.

While the increase in social grant expenditure (in partial fulfilment of the State's constitutional obligations) is to be welcomed, the poverty gap in rand terms in 2004 was still some R35 billion per annum in 2004. This sounds, and is, a large sum of money to redistribute each year. It was, however, less than three per cent of GDP in 2004 - that is what it would take to eradicate income poverty, if some way of delivering it (with near perfect targeting) could be found.

Three grants, as we noted above, do most of the work: the old age pension, child support grants and disability grants. It is important to bear in mind that none of these is intended to meet the needs of the unemployed, although, through the process known as benefit dilution, the unemployed almost certainly share this source of income. Old age pensions have the greatest impact on poverty. In 2004, the approximately two million pensions raised about 1.5 million people in 600000 households over the poverty line.

Five million child support grants look as though they lifted about 900000 people in 150000 households out of poverty. In terms of the numbers of beneficiaries, the grant with the largest increase was the child support grant. This had a relatively limited effect on the numbers living below the poverty line, however, because of the small size of the CSG, 
and because many of the households into which the grants flow are so very poor, having no other sources of income (which implies, of course, that the grants are well targeted). ${ }^{70}$

Next in importance to these two is the disability grant. Estimating its impact poses serious problems. Since most of the recipients of disability grants are poor, it is appropriate to allocate most of the money paid out in the form of disability grants to a reduction of the poverty gap. The same cannot be said about headcounts. This is because, as noted above, the costs of meeting the special needs of the disabled are not known with any precision. The degree to which the grant lifts them (and the households in which they are located) out of poverty, cannot, therefore, be determined.

Up until recently, the number claiming disability grants (and foster care grants) spiralled rapidly upwards, a wholly predictable consequence of (a) the AIDS epidemic, and (b) the yawning gap in South Africa's social protection system. Apart from the few hundred thousand reached (each for a short while) by the EPWP, there is effectively no social protection for the working age population. As a consequence, the number of disability grants paid grew from 613000 in April 2002 to 694000 in April 2002, and then to 1.27 million in April 2004 (IGFR, 2004, Table 6.14, p.76). One of the important explanations of this, according to Delany et al (2005) is poverty and unemployment. In one of the areas in which the study conducted in-depth interviews, it was reported that:

"the disability grant is viewed as 'igrant yokuhlupheka' or 'the grant for the poor people', both by the general public and some involved in the assessment process." (2005, Section 6.2.2.1)

a perception that is by no means limited to that particular locality. So bad was poverty that the study (by CASE) found evidence of the desperate decision by sick people to sacrifice their health (remain ill) in exchange for the grant. Given government's concern

$70 \quad$ The poverty-reducing effects of the child support grant are moderated by what appears to be fairly large scale abuse of the system by households at the upper end of the income distribution. The 2005 GHS suggests that among a total of 5.8 million grants disbursed, 444000 went into households where monthly expenditure was between R5000-9999, and a further 180000 into households where income exceeded R10 000 per month (own calculations on GHS 2005 data set, correction for income under-reporting of 75 per cent was used, and income from all sources, except migrant remittances was taken into account). Since 2005, government has taken active steps to combat benefit fraud (see below), so it may be that the GHS is picking up the results of these malpractices before the crackdown began. At any event, the fraud makes that other chestnut 'young girls falling pregnant simply to claim the child support grant' (a conservative favourite) pale into insignificance, as well it should. From fieldwork conducted between February and July 2005, de Koker et al (2006, Vol. 3, p.658) found that less than five per cent of child support grant claimants were aged less than 21 years, effectively giving the lie to the rumour of hordes of teenagers rushing to claim the grant. 
with 'perverse incentives' in the social grant system, finding ways to halt the growth in the number of successful applications for disability benefits was obviously a matter that exercised the minds of those whose job it is to act on such things. Control seems to have been regained, presumably by tightening up (and medicalising) the assessment procedures (Nattrass, 2006, p.7). ${ }^{71}$ By March 2006 the number of disability grant beneficiaries had stabilised at about 2.13 million (Plaatjies, 2006, Slide 6). If trends observed up until 2004 had continued into the future, disability grants would have overtaken the old age pensions in terms of numbers in a few years. That would have made a substantial contribution to poverty reduction. The threat (likelihood?) of such an outcome appears, at least for the meanwhile to have been averted, albeit at potentially very high cost (Nattrass, 2006, p.7). Although the rapid growth in the numbers of disability grants undoubtedly made an increasing contribution to the reduction in poverty, it is nevertheless still not appropriate to assume that the grants succeeded in eliminating poverty in all of the households into which they flowed. The special needs of many of the disabled must have gone unmet in the face of the extreme poverty of the households in which they lived.

$71 \quad$ Minister Skweyiya (of the national Department of Social Development) was reported as stating that more than 20 per cent of disability grants were obtained fraudulently. See Mail \& Guardian online, 5 May 2005, in the article by Donwald Pressly headed "Ninety thousand confess to welfare grant fraud". The article refers as well to the 41000 public servants in receipt of grants, all of whom were being investigated. 


\section{Conclusion}

Stories about poverty and unemployment in South Africa differ, depending on who is telling them. Differences of interpretation are less easily justified in the case of unemployment, than they are in the case of poverty. Government appears not to have much faith in the 'official' figures gathered by the biannual Labour Force Surveys. ${ }^{72}$ No less a personage than the President himself, as we have seen, prefers the appearance of casual observation (the non-appearance of '... at least 4 million South Africans walking about in our villages, our towns and cities "actively looking for work" ') to the essence portrayed by the LFSs. Social commentators are, of course, perfectly at liberty to reject the LFS findings - they may do so on the basis of casual empiricism; they could turn to surveys like the AMPS, ${ }^{73}$ or even, as some have, to proxies like the Unemployment Insurance Fund records. If they do not do that, they then discover that apart from the odd lapse, the (revised) ${ }^{74}$ LFSs tell a fairly coherent tale. ${ }^{75}$ That tale does not accord with government's oft-repeated claim that (one of the causes of) the continuing unemployment problem is the 'fact' that the rate of growth of the numbers of economically active, exceeds that of the working age population. ${ }^{76}$ Everybody knows that the unemployment problem is serious - nobody can say for certain why it is so bad. Taking refuge in a mistaken interpretation of events between 1996 and 2005 contributes nothing to its solution. Nor does repetition of the slogan 'we are on track to halve unemployment by 2014' - careful analysis suggests that there is little basis, other than faith, to underpin this assertion - there are simply too many unknowns to permit statements of this sort to be made with confidence (Meth, 2004; 2006c).

Unemployment is difficult to measure, employment more so. Poverty measurement, however, is in a league of its own. Surprisingly, given the fact that poverty eradication (or at least, poverty alleviation) is one of government's most important goals, no national

72 The rejection of 'official' poverty estimates in South Africa (Statistics South Africa, 2002) was even more emphatic. It is ironic that the poverty estimates that currently enjoy favour at the highest political level are generated from 'unofficial' (private sector) data.

73 The economic activity question in the 2004 AMPS (Question PD2) asks; "Which one of these statements best describes your working life?" Respondents are offered the options of working full-time or working part-time. If they are not working, they are invited to select among 'housewife', 'student', 'retired' or 'unemployed'. This simplicity contrasts strongly with the LFS questionnaires. The quality of the information collected in the AMPS is anybody's guess.

74 See statistical release P0210, 26 September 2005, and subsequent LFSs.

75 About the October Household Surveys, it is less easy to be sure.

76 It is only possible to tell this story if one willfully ignores the obvious break between the OHS series, which ends in 1999, and the LFS series, which commences in 2000. 
survey, specifically dedicated to the task of measuring poverty (and inequality) has been conducted since the dawn of democracy. Academics interested in the subject have thus had to make do with whatever has been available. ${ }^{77}$ Both my results (Meth 2006a; 2006b) and those of van der Berg et al (2005) are further instances of academics 'making-do'. As noted above, the decision by van der Berg and his co-authors to make use of the AMPS data is bold and innovative. Such are the uncertainties of their methodology, however, that their results should be regarded as tentative and exploratory, rather than authoritative. The political attractiveness of the results, unfortunately, is such that important users in government have shown themselves incapable of resisting the allure of figures that say what they, the users, want to hear. How much these users were emboldened by the way in which van der Berg et al put out their results is not easy to say. The results have enjoyed extensive coverage in the press, on the radio and on television. Here is the way in which their paper's abstract presents the findings:

"To steer clear of an unduly optimistic conclusion, assumptions are chosen that would tend to show the least decline in poverty. Whilst there were no strong trends in poverty for the period 1995 to 2000, both data series show a considerable decline in poverty after 2000, particularly in the period 20022004. Poverty dominance testing shows that this decline is independent of the poverty line chosen or whether the poverty headcount, the poverty ratio or the poverty severity ratio are used as measure. We find likely explanations for this strong and robust decline in poverty in the massive expansion of the social grant system as well as possibly in improved job creation in recent years." (van der Berg et al, 2005, p.2, emphasis added)

Using the LFSs as primary data source, my calculations suggest that not only are headcounts likely to have been higher than van der Berg et al suggest, but also that the fall in poverty was likely to have been much smaller. The LFSs appear as well, to suggest that 'improved job creation' played little or no role in such reduction of poverty as did occur. My results are tentative, because of the numerous obstacles that have had to be surmounted. That said, the LFSs (whatever other shortcomings as data sources they may have), do allow the poverty question to be addressed, almost independently, from both the income and the expenditure sides. This is a strong point in their favour. Because

77 A few surveys attempt to gather data in smaller jurisdictions, the KwaZulu-Natal Income Dynamics Study, being a notable example. 
the surveys collect data on both income and expenditure, it is possible to use simple imputation to reduce missing or implausible figures on either side to a minimum. To the extent that it is able, the 2004 GHS, which also collects income and expenditure data, offers some support to the conclusions generated by the LFS.

Painless, the process of extracting poverty information from official statistics, certainly is not. A great deal of guesswork (some of it educated, some of it less so) has to be done. Similar strictures apply to van der Berg and his colleagues - like the rest of us, they are forced to make a variety of assumptions to compensate for deficiencies in the data they use. This means that the quality of all of our (guess) estimates leaves more than a little to be desired. In short, there is much work to be done, and a number of problems to be solved before any of the household surveys conducted in South Africa is capable of yielding more precise poverty estimates.

Since precision remains tantalizingly out of reach, the 'actual' headcount and the true magnitude of the poverty gap, and the ways that these have changed in recent years, must remain a matter for conjecture. This has implications for the way that all of us (producers and users of information about poverty) should behave. As poverty researchers, we must make the caveats that apply to all of our work so prominent that nobody can ever miss them. We should refrain from the unjustifiable use of words like 'robust', when 'fragile' and 'tentative' are more apposite. The spurious accuracy of single point estimates is to be avoided - all of the results from my work are approximations - in each case, they lie within a range, whose width, unfortunately, it is not very easy to estimate. Neither my results nor those of van der Berg et al are 'facts' - they are possibilities. That is the spirit in which they should be used.

Although one can (and should) attempt to prescribe the way in which one's research findings may be used, limiting the ways in which users actually deploy them once they are in the public domain, is not possible. Even if politicians, for example, were inclined to read 'directions for use', it is not obvious that they have much incentive to heed them. This could be so for many reasons. Often, they address audiences with notoriously short attention spans, among whom caveats would go unheard. Politicians impelled, either by inclination or necessity, to advance particular agendas (as part, for example, of the imperative of attempting to show that justice has been done), are also likely to ignore or downplay the fragility of research results. The only protection citizens have against this is a vigilant and well-informed press, able to dispel myth or self-serving assertion wherever they find it. This leads back to the uncomfortable conclusion that when 
academics engage in research in highly sensitive areas, they have to forsake the comfort of the ivory tower where arcane matters are normally settled (or not, as the case may be - as one economist quipped, some debates in the discipline drone on for centuries) for a cockpit in full view of a (probably) partisan public. Oh dear! 


\section{References}

Bhorat, Haroon, Naidoo, Pranushka and van der Westhuizen, Carlene. "Shifts in NonIncome Welfare in South Africa: 1993-2004", DPRU Working Paper 06/108, Development Policy Research Unit, University of Cape Town, May 2006.

Bhorat, Haroon and Kanbur, Ravi (eds). Poverty and Policy in Post-Apartheid South Africa, Cape Town: HSRC, 2006.

Blecher, Mark and Harrison, Stephen. "Health Care Financing" in South African Health Review 2006, Durban: Health Systems Trust, October 2006, pp.31-64.

Burger, Rulof. and Yu. Derek. "Wage trends in post-apartheid South Africa: Constructing an earnings series from household data ", Stellenbosch Economic Working Papers: 04/06

Byrne, David. Social exclusion, Buckingham: Open University Press, 1999.

Cole, Ken; Cameron, John and Edwards, Chris. Why economists disagree: The political economy of economics, Second edition, London: Longman, 1991.

Deaton, Angus. "Measuring Poverty in a Growing World (or Measuring Growth in a Poor World)", NBER Working Paper No. 9822, Cambridge, Massachusetts: National Bureau for Economic Research, 2003.

De Koker, Christell; De Waal, Liezel and Vorster, Jan. A profile of social security beneficiaries in South Africa, (three volumes), Department of Sociology \& Social Anthropology, Stellenbosch University, June 2006

Delany, Aislinn; Budlender, Debbie; Moultrie, Tom and Kimmie, Zaid. Investigation into the Increase in Uptake of Disability and Care Dependency Grants since December 2001, Researched For The National Treasury and The Department of Social Development by Community Agency For Social Enquiry (CASE), July 2005. Referred to as CASE (2005). 
Desai, Ashwin. We are the poors: Community struggles in post-apartheid South Africa, New York: Monthly Review Press, 2002.

Friedman, Steven. "A Voice for Some: South Africa's Ten Years of Democracy", in Piombo and Nijzink (eds), 2006, pp3-22.

Glennerster, Howard and Hills, John. The State of Welfare: The Economics of Social Spending, (Second Edition), Oxford: Oxford University Press, 1998.

Good, Kenneth. "Democracies and Poverty: Links and Associations", in Wilson et al (eds), 2001, pp.33-53.

Kanbur, Ravi. "Growth, Inequality and Poverty: Some Hard Questions", January 2004, downloaded from www.people.cornell.edu/pages/sk145, $1^{\text {st }}$ June 2004.

Kingdon, Geeta and Knight, John. "Are Searching and Non-searching Unemployment Distinct States when Unemployment is High? The Case of South Africa", unpublished paper, Centre for the Study of African Economies, University of Oxford, April 2000.

Lal, Deepak and Myint, H. The Political Economy of Poverty, Equity and Growth: A Comparative Study, Oxford: Clarendon Press, 1996.

Lawson, Tony. Economics and reality, London and New York: Routledge, 1997.

Leftwich, Adrian. "Bringing Politics Back In: Towards a Model of the Developmental State", Journal of Development Studies, February 1995, 31(3), cited in Swilling et al, 2005.

MacDonald, Michael. Why Race Matters in South Africa, Pietermaritzburg: University of KwaZulu-Natal Press, 2006.

Meth, Charles. "Sorry wrong number: A critical review of African labour force estimates", Research Monograph No. 4, Economic Research Unit, University of Natal, 1988. 
Meth, Charles. "Half Measures: The ANC's Unemployment and Poverty Reduction Goals", DPRU Working Paper No 04/89, Development Policy Research Unit, School of Economics, University of Cape Town, December 2004.

Meth, Charles. "Unemployment for beginners: Being a catalogue of some of the pitfalls and pleasures a do-it-yourself interpreter may encounter in the official statistics", New Agenda, Issue 19, Third Quarter 2005, pp.31-34.

Meth, Charles. "What was the poverty headcount in 2004 and how does it compare with recent estimates by van der Berg et al?", SALDRU Working Paper No 06/01, Southern African Labour and Development Research Unit, University of Cape Town, June 2006a.

Meth, Charles. "Income poverty in 2004: A second encounter with the recent van der Berg et al figures", Working Paper No. 47, School of Development Studies, University of KwaZulu-Natal, September 2006b.

Meth, Charles. "Half measures revisited: The ANC's unemployment and poverty reduction goals", in Bhorat and Kanbur (eds), pp.366-458, 2006c.

Nattrass, Nicoli. "Disability and Welfare in South Africa's Era of Unemployment and AIDS", CSSR Working Paper No. 147, University of Cape Town, February 2006.

National Treasury. Trends in Intergovernmental Finances: 2000/01-2006/07, Pretoria, August 2004. Referred to as IGFR 2004.

Pilger, John. Freedom Next Time, New York: Bantam Press, Random House, 2006.

Piombo, Jessica and Nijzink, Lia (eds). Electoral politics in South Africa: Assessing the first democratic decade, Cape Town: HSRC Press, 2006.

Plaatjies, Daniel. "Conditional Cash Transfer Programs in South Africa", South African Social Security Agency (SASSA), paper presented at the Third International Conference on Conditional Cash Transfers, Istanbul, June 26-30, 2006. Power Point presentation downloaded from http://info.worldbank. org/etools/icct06/DOCS/English/Day1/Plaatjies, $7^{\text {th }}$ December 2006. 
Ravallion, M. "Should poverty measures be anchored to the national accounts?", Economic and Political Weekly, (34), August 26, 2000, pp.3245-3252.

Ravallion, M. "Measuring aggregate welfare in developing countries: How well do national accounts and surveys agree?", Review of Economics and Statistics, (85), 2003, pp.645-652.

Scharpf, Fritz W, and Schmidt, Vivien A (eds). Welfare and work in the open economy. Volume I, From Vulnerability to Competitiveness, Oxford: Oxford University Press, 2000a.

Schlemmer, Lawrence, and Levitz, Charisse. Unemployment in South Africa: The Facts, the Prospects, and an Exploration of Solutions, Spotlight Series, January 1998, 1/98, Johannesburg: South African Institute of Race Relations.

Seekings, Jeremy. "The Broader Importance of Welfare Reform in South Africa", Social Dynamics, Winter 2002, 28(2), pp.1-38.

Standing, Guy; Sender, John, and Weeks, John. Restructuring the South African Labour Market (Presidential Commission to Investigate the Development of a Comprehensive Labour Market Policy), Geneva: ILO, 1996.

Statistics South Africa. Earning and spending in South Africa: Selected findings and comparisons from the income and expenditure surveys of October 1995 and October 2000, Pretoria: Statistics South Africa, 2002.

Swilling, Mark; van Breda, John; van Zyl, Albert and Khan, Firoz. "Economic PolicyMaking in a Developmental State: Review of the South African Government's Poverty and Development Approaches, 1994-2004", Research Report 3, Economic Policy and Poverty Alleviation Report Series, Centre for Civil Society, no date, but apparently published in 2005. Referred to as Swilling et al, 2005.

The Presidency. Towards a Ten Year Review: Synthesis Report on Implementation of Government Programmes, Policy Co-ordination and Advisory Services, (PCAS), referred to as (PCAS, 2003). 
The Presidency. A Nation in the Making: A Discussion Document on Macro-Social Trends in South Africa, Policy Co-ordination and Advisory Services, (PCAS), referred to as (PCAS, 2006).

van der Berg, Servaas, Burger, Ronelle; Burger, Rulof; Louw, Megan and Yu, Derek. "Trends in poverty and inequality since the political transition", Stellenbosch Economic Working Papers, No. 1 / 2005. Referred to as van der Berg et al, 2005.

Wilson, Francis; Kanji, Nazneen and Braathen, Einar (eds). Poverty Reduction: What Role for the State in Today's Globalized Economy? London and New York: Zed Books; Claremont: New Africa Education Publishing, 2001.

World Bank I The International Bank for Reconstruction and Development. World Development Report 2000/2001: Attacking Poverty, New York: Oxford University Press, 2001 (Referred to as World Bank, 2001). 